\title{
FCC TAX CERTIFICATES FOR MINORITY OWNERSHIP OF BROADCAST FACILITIES: A CRITICAL RE- EXAMINATION OF POLICY
}

\section{BRUCE R. WiLDE†}

About twenty years ago, the Federal Communications Commission (Commission or FCC) first considered the issue of racial minority group participation in the broadcasting industry. This issue arose following complaints that some broadcasters practiced discrimination in hiring. ${ }^{1}$ The Commission, recognizing "a national policy against discrimination in employment on the basis of race, religion, sex, or nationality,"2 concluded that its statutory mandate of regulating broadcasting in the public interest ${ }^{3}$ required taking action to ensure equal opportunity in the industry. In a rulemaking, the commissioners declared: "we simply do not see how the Commission could make the public interest finding as to a broadcast applicant who is deliberately pursuing or preparing to pursue a policy of discrimination-of violating the National policy." Accordingly, the Commission announced that it would entertain complaints of discrimination against broadcasters and would take action if a "substantial issue of discrimination" was raised. ${ }^{5}$ Later, the Commission required broadcasters to adopt equal opportunity programs ${ }^{6}$ and to file annual reports on their employment by racial categories. ${ }^{7}$ It also strongly suggested that broadcasters should take "affirmative action" to increase minority employment. ${ }^{8}$

† B.A. 1973, Columbia University; J.D. Candidate 1990, University of Pennsylvania. The author is a former radio and television news broadcaster, most recently at WHBF-TV, Rock Island, Illinois, from 1978-87.

I See Petition for Rulemaking to Require Broadcast Licensees to Show Nondiscrimination in their Employment Practices, 13 F.C.C.2d 766, 769 (1968).

2 Id. at 767.

3 See infra notes 25-32 and accompanying text.

413 F.C.C. $2 d$ at 769.

5 Specifically, the Commission would refer complaints to the Equal Employment Opportunity Commission or other appropriate state or local agencies for investigation, or undertake its own investigation. On a finding of substantial discrimination, the Commission would set the issue for hearing. Id. at 772 . (1969).

6 See Nondiscrimination in Broadcast Employment, 18 F.C.C.2d 240, 243

7 See Petition for Rulemaking to Require Broadcast Licensees to Show Nondiscrimination in Employment Practices, 23 F.C.C.2d 430, 430 (1970).

8 See Nondiscrimination in the Employment Policies and Practices of Broadcast 
The Commision's equal opportunity stance was also supported by a prior long-standing Commission policy which held that increased diversity of viewpoints in broadcast programming is in the public interest. ${ }^{9}$ Under that policy, the Commission has long assumed that viewpoint diversity can be increased by promoting diversity in the ownership of the means of mass communication. ${ }^{10}$

These two policy strands merged in a single policy favoring minority ownership of broadcast stations. At court direction, ${ }^{11}$ the Commission extended a limited preference in comparative licensing proceedings to applicants demonstrating significant minority involvement in their ownership and management structures. ${ }^{12}$

In 1978, the Commission further developed this policy by creating economic incentives for current broadcast licensees to sell their interests to minority-controlled business entities. ${ }^{13}$ One incentive,

Licensees, 60 F.C.C.2d 226, 235 (1976) (adopting a sample equal opportunity/ affirmative action program); Nondiscrimination in the Employment Policies and Practices of Broadcast Licensees, 54 F.C.C.2d 354 (1975) (proposing a sample program).

The current FCC equal employment opportunity rules are found at 47 C.F.R. $\S 73.2080$ (1988).

9 See Policy Statement on Comparative Broadcast Hearings, 1 F.C.C.2d 393, 394 n.4 (1965) (stating that "the first amendment to the Constitution of the United States 'rests on the assumption that the widest possible dissemination of information from diverse and antagonistic sources is essential to the welfare of the public' " (quoting Associated Press v. United States, 326 U.S. 1, 20 (1944))).

I0 See id. at 394 (claiming that "[d]iversification of control is a public good in a free society, and is additionally desirable where a government licensing system limits access by the public to the use of radio and television facilities").

11 See TV 9, Inc. v. FCC, 495 F.2d 929, 937-38 (D.C. Cir. 1973), cert. denied, 419 U.S. 986 (1974).

12 See Statement of Policy on Minority Ownership of Broadcasting Facilities, 68 F.C.C.2d 979, 982 (1978) [hereinafter 1978 Policy Statement].

The FCC conducts a comparative proceeding when two or more legally qualified applicants seek the license to use a particular broadcast frequency and only one license can be granted. See 47 C.F.R. $\$ 73.3591$ (1988) (FCC will grant authorization without hearing when there is no "mutually exclusive application" and other requirements are met); 47 C.F.R. $\$ 73.3593$ (1988) (application will be designated for hearing if requirements of $\$ 3591$ are not met, including situation of competing qualified applicants). However, existing licensees in good standing are rarely subjected to comparative hearings because the Commission affords a comparative preference for substantial past public service. A competitor will be unable to overcome this preference unless the incumbent's record is especially bad. See Central Florida Enters., Inc. v. FCC, 683 F.2d 503, 506-10 (D.C. Cir. 1982) (approving Commission policy of renewal expectancy), cert. denied, 460 U.S. 1084 (1983).

The minority preference afforded in comparative proceedings is discussed infra at notes 33-37 and accompanying text. Details of the tax certificate program, which is the subject of this Comment, are discussed infra at notes 38-72 and accompanying text.

13 See 1978 Policy Statement, supra note 12, at 982-83. 
the distress sale policy, allows a licensee who faces a proceeding that might result in forfeiture of a valuable license to avoid the threat of total loss by transferring the licensed property to a minority entity at a below market "distress" price. ${ }^{14}$ In addition, the Commission announced that it would use its power to issue a certificate permitting deferral of capital gains $\operatorname{tax}^{15}$ in cases where a licensee sells to a minority buyer. Provided the seller re-invests the proceeds within a specified time in another company that holds a broadcast license (or in other property considered "similar or related in service or use"), ${ }^{16}$ the transaction will be treated as if it were an involuntary conversion, and taxation of the gain is deferred as long as the replacement property is held. ${ }^{17}$ This specific program (program or tax certificate program) is the subject of this Comment.

By October 18, 1988, the Commission had issued 166 such certificates for minority ownership. ${ }^{18}$ Indeed, use of the program appears to have increased since $1986,{ }^{19}$ when tax legislation eliminated preferential treatment of capital gains income. ${ }^{20}$ As of 1986, $2.1 \%$ of all operating radio and TV stations in the United States were minority-owned or controlled - a total of 209 radio stations and $38 \mathrm{TV}$ stations. ${ }^{21}$ This percentage is far less than the fraction of minority-group people in the United States, which is about $20 \% .^{22}$

14 See Lebowitz, FCC Minority Distress Sale Policy: Public Interest v. the Public's Interest, 1981 WIs. L. REv. 365, 366 (discussing various aspects of minority distress sale policy).

The distress sale policy was recently held to violate the fifth amendment due process rights of a non-minority-controlled applicant which sought a license that the Commission permitted to be assigned under the policy. See Shurberg Broadcasting of Hartford, Inc. v. FCC, 876 F.2d 902 (D.C. Cir. 1989).

15 The Commission is given this power by 26 U.S.C. $\S 1071$ (1982). For the text and an explanation of the statute, see infra notes $40-47$ and accompanying text.

1626 U.S.C. $\$ 1071$ (a) (1982).

17 See 26 U.S.C. $\$ 1033(\mathrm{a})(1)$ (1982) (governing tax treatment of involuntary conversions of similar property); infra notes $41-43$ and accompanying text.

The program has since been extended to cover sales of cable television facilities, and tax certificates are available to investors who provide start-up financing for minority broadcast enterprises when the investors subsequently sell their interest in the minority business. See infra notes 69-72 and accompanying text.

18 See FCC Consumer Assistance and Small Business Division, Office of Public Affairs, Minority Ownership Lists (updated Oct. 18, 1988) (front page) (on file with University of Pennsylvania Law Review).

19 See id.

20 See Tax Reform Act of 1986, Pub. L. No. 99-514, §§ 301, 311, 100 Stat. 2085, 2216-17, 2219 (codified in scattered sections of 26 U.S.C.).

21 See National Association of Broadcasters, Minority Broadcasting Facts 6,8 (1986).

22 In 1980, percentages of minority groups in the U.S. population were: Black, 11.7\%; Spanish origin, 6.4\%; Asian and Pacific Islanders, 1.5\%; American Indian, 
Yet, it is a significant increase from 1978-the year the tax certificate program started-when it was reported that less than $1 \%$ of commercial broadcast stations were minority-controlled. ${ }^{23}$ The exact amount of revenue the government loses because of the program has not been publicly disclosed and may be unknown to the relevant decisionmakers. The cost is probably about one hundred million dollars a year. ${ }^{24}$

Whether minority ownership of broadcasting stations is a worthwhile objective that government should encourage is a matter of political and social policy that is beyond the scope of this Comment. However, the tax certificate program does raise several questions that are primarily legal, including the following:

1. Is conditioning the grant of a tax benefit based on the race of the buyer of a broadcasting station a lawful exercise of the Commission's administrative discretion?

2. Is this type of racial classification by government consistent with the equal protection and due process guarantees of the fourteenth amendment?

3. Is the current structuring of the program as an element of the income tax system an efficient and effective means of pursuing the Commission's minority-ownership policy?

4. Assuming that the Commission's policy is to be pursued through the tax system, is it being properly administered and controlled from the standpoints of effectiveness, efficiency, and avoidance of abuse?

These questions will be considered in turn. Statutory authority is discussed in Part II, constitutionality is dealt with in Part III, tax policy issues are addresed in Part IV, and Part V considers administrative problems with the existing program and how those problems might be reduced. But first it is necessary to describe more fully the development and functioning of the program as it now exists.

Eskimo, and Aleut, $0.6 \%$; other nonwhite races, $3.0 \%$. See 1 BurEau of the Census, U.S. Dep't of Commerce, 1980 Census of Population, ch. B, pt. 1, at 1-12, fig. 9.

23 See 1978 Policy Statement, supra note 12, at 981 (quoting Federal Communications Commission's Minority OWNership Task Force, Minority OWNERSHIP REPORT (1978)).

24 See Staff of Joint Comm. on Taxation, 101st Cong., 1st Sess., Estimates of Federal Tax Expenditures for Fiscal Years 1990-1994, at 15 (Joint Comm. Print 1989) (estimating revenue loss for all FCC tax certificates, including those for minority ownership, at 100 million dollars a year for corporate tax returns and less than $\mathbf{5 0}$ million dollars a year for individual returns). 


\section{Development of the Tax Certificate Program}

\section{A. The Public Interest in Minority Ownership}

The Communications Act of 1934, as amended, ${ }^{25}$ gives the FCC exclusive authority to determine who may operate a broadcasting station within the United States. ${ }^{26}$ The Commission is directed to grant applications for station licenses "if public convenience, interest, or necessity will be served thereby."27 Once a license is granted, the licensee may not assign it, nor may control of the licensed business entity be transferred to any other person, unless application is made to the Commission and it finds that the assignment or transfer is in the public interest. ${ }^{28}$ The Commission also has specific statutory authority to "[m]ake such rules and regulations and prescribe such restrictions and conditions, not inconsistent with law, as may be necessary to carry out the provisions of [the statute]."29

The Supreme Court has held that "[ $t]$ his mandate to the FCC to assure that broadcasters operate in the public interest is a broad one, a power 'not niggardly but expansive." "30 The Commission has
25 See 47 U.S.C. $\S \S 151-610$ (1982).
26 See 47 U.S.C. $\S \S 301,307$ (1982).
2747 U.S.C. $\$ 307$ (a) (1982).

$28 \mathrm{See} 47$ U.S.C. $\$ 310$ (d) (1982). Courts consistently have held that an FCC license to operate a broadcast station is not personal property. See American Broadcasting Co. v. FCC, 191 F.2d 492, 497 (D.C. Cir. 1951) ("The policy of the [Communications] Act is clear that no person is to have anything in the nature of a property right as a result of the granting of a license." "quoting FCC v. Sanders Bros. Radio Station, 309 U.S. 470, 475 (1940))); 47 U.S.C. $\$ 309$ (h) (1982) ("The station license shall not vest in the licensee any right to operate the station nor any right in the use of the frequencies designated in the license beyond the term thereof nor in any other manner than authorized therein ....").

However, a licensee does have an effective power to assign her license or transfer control of the licensed entity to any other person of her choosing who would be eligible to receive the license. Section 310(d) provides, in part, that when a licensee applies for permission to assign or transfer control, "the Commission may not consider whether the public interest, convenience, and necessity might be served by the transfer, assignment or disposal of the permit or license to a person other than the proposed transferee or assignee." 47 U.S.C. $\$ 310$ (d) (1982). This means that "where permission is sought to assign a valid existing permit [or license], the only question is whether the proposed assignee possesses the minimum qualifications consistent with the "public interest, convenience and necessity." MG-TV Broadcasting Co. v. FCC, 408 F.2d 1257, 1264 (D.C. Cir. 1968).

Because the licensee in good standing effectively can control disposition of the license, she can demand as payment the capitalized value of the privilege of operating the station in the future.

2947 U.S.C. § 303(r) (1982).

30 Red Lion Broadcasting Co. v. FCC, 395 U.S. 367, 380 (1969) (quoting National Broadcasting Co. v. United States, 319 U.S. 190, 219 (1943)). 
long taken the position that the public interest is advanced by diversity of viewpoints expressed in broadcast programming, and it has assumed that viewpoint diversity will be increased by increasing diversity in ownership of the broadcast media. ${ }^{31}$ The courts generally have accepted this interpretation of the public interest. ${ }^{32}$

Beginning in the 1970s, the idea of promoting the public interest through ownership diversification was easily extended to encompass the view that, other things being equal, the public interest would be served by giving an advantage to members of racial minority groups in applying for station licenses. This new view was first adopted by the Court of Appeals for the District of Columbia Circuit. In $T V$ 9, Inc. v. $F C C,{ }^{33}$ the court concluded that the Commission, under its existing comparative hearing criteria, should have given extra merit to an applicant corporation in which two black persons each owned approximately seven percent of the stock, and both were to be directors with some limited involvement in station management. The court said:

It is consistent with the primary objective of maximum diversification of ownership of mass communications media for the Commission in a comparative license proceeding to afford favorable consideration to an applicant who, not as a mere token, but in good faith as broadening community representation, gives a local minority group media entrepreneurship. . . . We hold only that when

31 When more than one qualified applicant seeks the same broadcast license in a comparative proceeding, the Commission awards merit to the applicant who has less pre-existing ownership interests in other mass media, especially in the same market area and region where the proposed station is to be located. See Policy Statement on Comparative Broadcast Hearings, I F.C.C.2d 393, 393-95 (1965) [hereinafter 1965 Policy Statement]. The Commission also has long enforced limits on the number of radio and TV station licenses one person may hold nationwide. The current limit is 12 licenses in each service (AM, FM, or TV), and no person may hold licenses for TV stations serving more than $25 \%$ of the TV households nationwide. (However, minority-group owners are allowed 14 stations per service and up to $30 \%$ of the national TV market.) Also, no person may hold two licenses in the same service in the same market area, nor may a radio station license be granted to a person who already owns a TV station or daily newspaper in the market, nor may a TV station license be granted to a person who already owns a radio station or daily newspaper in the same market. See 47 C.F.R. $§ 73.3555$ (1988); Amendment of Section 73.3555 of the Commission's Rules, 100 F.C.C.2d 17 (1984) (latest amendment of the multiple ownership rules).

32 See TV 9, Inc. v. FCC, 495 F.2d 929, 937 (D.C. Cir. 1973), cert. denied, 419 U.S. 986 (1974); Citizens Communications Center v. FCC, 447 F.2d 1201, 1213 n.36 (D.C. Cir. 1971).

33495 F.2d 929 (D.C. Cir. 1973), cert. denied, 419 U.S. 986 (1974). 
minority ownership is likely to increase diversity of content, especially of opinion and viewpoint, merit should be awarded. ${ }^{34}$

On petition for rehearing, Judge Fahy, speaking for the court, made clear that he was relying on both ownership and participation in management by minority persons, and he did not decide whether minority ownership alone would be entitled to merit. He added that he did not envision an absolute preference for minority applicants, but only that minority involvement should be given some weight in the overall comparative balancing formula. ${ }^{35}$ The $T V 9$ decision represented a significant policy initiative by a court that normally gives substantial deference to Commission policy choices. ${ }^{36}$ But the Commission adopted the court's policy as its own, and ever since, it has given comparative merit to applicants who have substantial minority-group ownership when the minority owners will be actively involved in dayto-day station management. ${ }^{37}$ The requirement of "integration" of

34 Id. at $937-38$.

35 See id. at 941.

36 See, e.g., Winter Park Communications, Inc. v. FCC, 873 F.2d 347, 352 (D.C. Cir. 1989) ("The FCC has broad discretion under section 307(b) [of the Communications Act] to determine the public interest ...."); Syracuse Peace Council v. FCC, 867 F.2d 654, 658 (D.C. Cir. 1989) ("In making a public interest judgment under the Communications Act, the Commission is exercising both its Congressionally-delegated power and its expertise; it clearly enjoys broad deference ...." (footnote omitted)); Health \& Medicine Policy Research Group v. FCC, 807 F.2d 1038, 1043 (D.C. Cir. 1986) ("[T]he Commission's judgment regarding how the public interest is best served is entitled to substantial judicial deference." (quoting FCC v. WNCN Listeners Guild, 450 U.S. 582, 596 (1981))).

37 See 1978 Policy Statement, supra note 12, at 982 ("[The Commission's] Administrative Law Judges have afforded comparative merit to applicants for construction permits where minority owners were to participate in the operation of the station. The Commission itself has ordered the expedited processing of several applications filed by applicants with significant minority ownership interests." (footnotes omitted)).

The merit given for minority-group ownership is considered to be an "enhancement" of the principal comparative criterion of "integration of ownership and management." Enhancement of the underlying percentage of ownershipintegration is also allowed for past or proposed local residence of integrated owners, past participation in civic activities by integrated owners, and past broadcast experience of integrated owners. See Formulation of Policies and Rules Relating to Broadcast Renewal Applicants, 3 F.C.C. Rcd. 5179, 5189 (1988).

Integration of ownership and management is one of six "significant factors" the Commission has long considered in comparative licensing proceedings. Those factors are (1) diversification of control of mass media, (2) participation in operation by owners (integration of owners in management), (3) proposed programming service, (4) past broadcasting record of applicant that is significantly above or below average, (5) efficient use of the frequency, and (6) any significant deficiencies in an applicant's character. See 1965 Policy Statement, supra note 31, at 394-99.

The 1973 policy development, placing merit for ownership by minority group 
ownership and management in order to obtain the minority preference is an important one which, significantly, has not been carried over into the tax certificate program.

\section{B. Use of the Tax Certificate Authority}

In 1978, the Commission declared that the previous measures had not been sufficient:

[W]e are compelled to observe that the views of racial minorities continue to be inadequately represented in the broadcast media. This situation is detrimental not only to the minority audience but to all of the viewing and listening public. Adequate representation of minority viewpoints in programming serves not only the needs and interests of the minority community but also enriches and educates the non-minority audience. ${ }^{38}$

The 1978 Policy Statement reiterated the "diversity of ownership equals diversity of viewpoints" premise and then announced that the Commission would consider issuing tax certificates for sales of broadcast facilities to "parties with a significant minority interest" in cases where "there is a substantial likelihood that diversity of programming will be increased." 39

members within the broader factor of integration of ownership in management, may explain why credit in comparative hearings is given only for minority-group owners who will work in management. Set New Continental Broadcasting Co., 88 F.C.C.2d 830, 844 (Rev. Bd. 1981) ("[T]he relevant consideration is not minority ownership per se, but rather the extent to which minority owners are integrated into the proposed station's operation." (citing WPIX, Inc., 68 F.C.C.2d 381, 411 1-12 (1978))).

381978 Policy Statement, supra note 12, at 980-81 (footnotes omitted).

One commentator suggests that in developing the tax certificate program, the Commission was motivated not so much by a desire to further increase minority participation in broadcasting, but rather to compensate, through a minority ownership policy, for its own reduced commitment to equal employment opportunity enforcement and the ascertainment process by which broadcasters had been obliged to seek programming suggestions from community leaders, including those in minority communities. See Honig, The FCC and Its Fluctuating Commitment to Minority Ownership of Broadcast Facilities, 27 How. L.J. 859, 864-73 (1984).

391978 Policy Statement, supra note 12, at 982-83. It should be noted that the supposed advantages of diversity through minority ownership are not considered to be dependent on the presence or absence of any particular racial and ethnic makeup of the community being served, whether the context is a comparative license hearing or an application for a tax certificate. See New Continental Broadcasting Co., 88 F.C.C.2d 830, 844-45 (Rev. Bd. 1981) (refusing to give applicant broadcast station owned by combination of black and hispanic interests more minority ownershipintegration enhancement than a competitor wholly owned by hispanics, the Review Board asserted that diversity "means exposing persons of one cultural stripe to the possibly differing views of others with differing environmental backgrounds and experiences"). 
The 1978 Policy Statement represented a completely new application of the tax certificate authority. Under section 1071 of the Internal Revenue. Code:

[i]f the sale or exchange of property (including stock in a corporation) is certified by the [FCC] to be necessary or appropriate to effectuate a change in a policy of, or the adoption of a new policy by, the Commission with respect to the ownership and control of radio broadcasting stations, such sale or exchange shall, if the taxpayer so elects, be treated as an involuntary conversion of such property within the meaning of section $1033 .^{40}$

Section 1033 provides that if the broadcast property is involuntarily exchanged for other property "similar or related in service or use to the property so converted, no gain shall be recognized." 4 I If the station is sold for money, the gain is recognized except to the extent that the proceeds are re-invested in similar or related property within two years of the close of the tax year in which the gain was realized. ${ }^{42}$ Section 1071 provides that stock in a corporation that operates a broadcasting station is automatically considered to be similar or related property. A taxpayer who does not wish to invest in related property can also avoid recognition by charging the gain realized against basis in any other depreciable property remaining in her hands after the sale or acquired within the same tax year. ${ }^{43}$

The language of section 1071 was first added to the Code as part of the Revenue Act of $1943 .{ }^{44}$ The Commission was then trying to eliminate common ownership of competing radio stations within the same market. Congress intended to provide relief for licensees who had to sell or exchange such stations as a condition of obtaining license renewal. ${ }^{45}$ While there is no indication that Congress

4026 U.S.C. $\$ 1071$ (1982); see also 26 C.F.R. $\$ \$ 1.1071-1$ to $1.1071-3$ (1989) (elaborating on the specific applications of 26 U.S.C. $\$ 1071$ ).

4126 U.S.C. § 1033(a)(1) (1982); see also 26 C.F.R. § 1.1033(a)-1 (1988) (setting forth general and special applications of $\S 1033$ involuntary conversions).

42 See 26 U.S.C. § 1033(a)(2)(A)-(B) (1982). For a complete discussion of the meaning of property "similar or related in service or use," other issues relating to tax treatment of the certificate holder, and use of the tax certificate authority to encourage breaking up grandfathered radio-TV and broadcast-newspaper crossownerships, see Blake \& McKenna, Section 1071: Deferral of Tax on FCC Sanctioned Dispositions of Communications Properties, 36 TAX L. REv. 101 (1980).

43 See 26 U.S.C. $\$ 1071$ (a) (1982).

44 Pub. L. No. 78-235, § 123(a), 58 Stat. 21, 44 (1944).

45 See H.R. Conf. Rep. No. 1079, 78th Cong., 2d Sess. 49-50 (1944), reprinted in J. Seidman, Legislative History of Federal Income and Excess Profits Tax Laws, 1953-1939, at 1603 (1954); S. REP. No. 627, 78th Cong., 1st Sess. 23, 53-54 (1943), reprinted in J. SEIDMAN, supra, at 1602-03. 
intended the provision to be used for any other purpose, the language is not specific, so the tax certificate authority may be just as broad as the Commission's regulatory authority to make and change policies concerning ownership and control of broadcasting stations. ${ }^{46}$ The Commission's power to use tax certificates to promote minority ownership generally has not been questioned. ${ }^{47}$

What has been disputed is how to define the amount and type of minority involvement an assignee must have in order to make the assignor eligible for a tax certificate. In its 1978 Policy Statement, the Commission noted: "We currently contemplate issuing a certificate where minority ownership is in excess of $50 \%$ or controlling. Whether certificates would be granted in other cases will depend on whether minority involvement is significant enough to justify the certificate in light of the purpose of the policy announced herein." 48

\section{What is Minority-Owned or -Controlled?}

For the first five years of the program, the Commission generally required that minority-group members hold at least a $51 \%$ ownership interest in the assignee. ${ }^{49}$ Forty-five percent ownership, where

46 The original version of the statute spoke of transactions "certified by the [FCC] to be necessary or appropriate to effectuate the policies of the Commission with respect to the ownership and control of radio broadcasting stations." See Revenue Act of 1943, Pub. L. No. 78-235 § 123(a), 58 Stat. 21, 44 (1944). The current language - "necessary or appropriate to effectuate a change in a policy of, or the adoption of a new policy by, the Commission"-was substituted in 1958 to make it clear that a tax certificate is available only when a station was lawfully acquired under Commission rules and later disposed of in compliance with a new or changed rule. See Technical Amendments Act of 1958, Pub. L. No. 85-866, § 48, 72 Stat. 1606, 1642 (1958); H.R. REP. No. 775, 85th Cong., 1st Sess. 29 (1957).

Previously, the Commission had allowed certificates for the value of a whole package transaction, even though an ownership policy was only advanced by disposition of part of the package, when the seller showed that all the property involved constituted a "single operational entity" and from a practical business standpoint had to be sold as a unit. Apparently, the Commission decided this treatment was excessively generous: and, in 1982, announced that it would issue tax certificates only for that property disposition which "directly effectuates" FCC policy. See Policy Statement on Issuance of Tax Certificates, 92 F.C.C.2d 170, 171 (1982) (emphasis in original).

47 However, the Commission itself once argued in a court brief that the tax certificate program and other race- and gender- preference programs may be unconstitutional. This position regarding the tax certificate program has never been adopted by a court, and the Commission appears to have changed its collective mind. See infra notes 73-148 and accompanying text (discussing constitutionality and lawfulness of the program).

481978 Policy Statement, supra note 12, at 983 n.20.

49 See Blake \& McKenna, supra note 42, at 106-07 nn.23-24 (citing 1978 Policy Statement, supra note 12 , at 979,983 n.20). 
the minority persons also had the right to vote an additional $10 \%$ of the stock through a voting trust arrangement, was held to be insufficient. ${ }^{50}$ Similarly, the Commission denied a certificate where $30 \%$ of the transferee corporation was owned by minority persons and three of the seven directors were minorities, even though minority directors would comprise a majority of the "personnel committee" and the "programming committee." 51 The Commission concluded:

[The transferee] has failed to demonstrate that its minority principals will exercise permanent control over station operations. A persuasive showing of permanent minority control is required so that the Commission may avoid the intrusive and time-consuming task of monitoring station programming and personnel decisions in the future to insure compliance with the policy under which the tax certificate was granted. ${ }^{52}$

The controlling share of ownership, however, need not be held by a single minority person. It appears instead that any number of minority-group members may aggregate their shares to achieve "legal control." The apparent result of this is that a non-minority-group person could be the largest single shareholder with up to $49 \%$ ownership, while a dozen minority-group persons shared $51 \%$ and the entity would be considered minority-controlled.

In addition, "Iegal control" sometimes may be found short of $51 \%$ ownership. In 1978 , the Commission granted a certificate where the transferee was a limited partnership in which the sole general partner was a minority person owning $11.4 \%$ of the equity and total minority ownership equalled $45.5 \% .^{53}$ In 1982 , the Commission established a general rule for limited partnerships: a tax certificate could be issued in transfers to limited partnerships if the general partner or partners are minority persons and own more than $20 \%$ of the partnership. ${ }^{54}$ The Commission added that "in order to avoid 'sham' arrangements, we will continue to review such arrangements to ensure that complete managerial control over the station's operations is reposed in the minority general partner(s)."55

It is not always easy to determine if minority control of a busi-

50 See Long-Pride Broadcasting, 48 Rad. Reg. 2d (P \& F) 1243, 1244 (1981).

51 See Nevada Indep. Broadcasting Corp., 71 F.C.C.2d 531, 532-33 (1979).

52 Id. at 534.

53 See William M. Barnard, 44 Rad. Reg. 2d (P \& F) 525, 526-27 (1978) (granting certificate after concluding the minority general partner would have "exclusive authority to manage and control the affairs of [the station]').

54 See Commission Policy Regarding the Advancement of Minority Ownership in Broadcasting, 92 F.C.C.2d 849, 855 (1982) [hereinafter 1982 Policy Statement].

55 Id. at 855. 
ness is bona fide or is a "sham." Some indications of Commission thinking can be gleaned from analogous cases involving requests for comparative merit on the basis of integration of minority partners into the management of an applicant. One partnership received credit for integration of an hispanic partner who was to manage the station even though his capital contribution was entirely financed by the other non-minority partner. ${ }^{56}$ Similarly, another limited partnership was granted credit for $100 \%$ integration of ownership in management where both general partners were minority-group members, even though their cash contributions constituted less than $1 \%$ of the total equity investment. ${ }^{57}$ Where a minority general partner has extensive experience in broadcast management and some of the passive investors are also minorities, the Commission has indicated that it will respect the claim of minority control, even if the limited partners can remove the general partner for a "material default" under the partnership agreement. ${ }^{58}$ Finally, in the case of a corporate assignee, a tax certificate was issued where the minoritygroup shareholder held only $21 \%$ of the shares, but had voting control because his class of shares carried more votes than the other shares. ${ }^{59}$

56 The Commission concluded that the partnership agreement established the bona fides of the arrangement by giving the minority partner "real authority," including negative control over major financial decisions. See Kist Corp., 102 F.C.C.2d 288, 291-92 (1985), aff 'a' mem., 801 F.2d 1436 (D.C. Cir. 1986).

57 See Genesee Communications, Inc., 2 F.C.C. Rcd. 7252, 7256 (1987) (initial decision of Administrative Law Judge). One-hundred percent of the ownership was considered to be integrated because the general partners had complete managerial control. Id. at 7254-55.

58 See Independent Masters, Itd., 104 F.C.C.2d 178, 189, 192 (Rev. Bd. 1986). The Commission concluded that the partnership agreement "provides some reasonable assurance that [the general partner] cannot be summarily or arbitrarily removed." Id. at 189.

59 The assignee corporation, WTVT Holdings, Inc., issued two classes of shares. The 210 class $A$ shares held by the minority-group shareholder carried four votes each. The 790 class $\mathrm{B}$ shares held by the non-minority-group shareholder carried one vote each. Thus, with just $21 \%$ of the total shares, the minority-group shareholder controlled $51 \%$ of the votes. See Articles of Incorporation of WTVT Holdings (March 4, 1987) (available in FCC license file of WTVT(TV)). On these facts, a tax certificate was issued. See Certificate Issued by the Federal Communications Commission Pursuant to Section 1071 of the 1954 Internal Revenue Code (26 U.S.C. Section 2071) (April 27, 1987) (tax certificate issued to the assignor, Gaylord Broadcasting Company) [hereinafter Tax Certificate].

In this case, the non-minority shareholder provided virtually all the financing for the transaction. The corporation was capitalized at just $\$ 1,000$, see Articles of Incorporation of WTVT Holdings, supra, and the non-minority shareholder agreed to arrange all financing for the purchase of WTVT. See Shareholder Agreement among WTVT Holdings, Inc., Clarence V. McKee and GNG-3, Inc., 2 (April 7, 1987) 
Once a station has been assigned to a minority-controlled owner and the assignee has been issued a tax certificate, the Commission will not permit the license to be retransferred for one year except to another minority owner, ${ }^{60}$ and it has declared an intention to "scrutinize routinely any subsequent application for transfer to guard against possible abuses."61 The Commission stated: "[T] re-sale of such a station to a non-minority at a profit would subvert our goal of increasing minority ownership of broadcast stations."62

\section{Who Is a Minority Person?}

In addition to the question of who has permanent legal control of the buyer-assignee, there may be a question of whether such persons qualify as "minority persons." In the 1982 Policy Statement, the Commission said: "For purposes of this statement, the term 'minority' includes American Indians or Alaskan Natives, Asians and Pacific Islanders, Blacks and Hispanics."63 The Commission cited as authority a prior amendment to the Communications Act in which Congress had specified which minority groups were to receive "preference" in cases where the Commission used a random lottery process to choose among qualified competing broadcast-license applicants. ${ }^{64}$ The Conference report on the amending act ${ }^{65}$ states: "It is the Conferees intention that the definitions in Office of Man-

[hereinafter WTVT Shareholder Agreement] (available in the FCC license file of WTVT(TV)).

The award of the WTVT tax certificate has been criticized and may not accurately reflect current FCC policy; however, the criticism has not concerned the equity structure of the transaction, but instead has centered on the lack of assurance that the minority partner will remain involved in the station in the future. See infra notes $183-88$ and accompanying text.

60 This one-year holding rule had previously been imposed only on persons who obtained a license through a comparative hearing. The Commission extended it to cover assignees under a tax certificate or the distress sale policy. See Amendment of Section 73.3597 of the Commission's Rules (Applications for Voluntary Assignments or Transfer of Control), 99 F.C.C.2d 971, 972, 974 (1985) [hereinafter Amendment of Section 73.3597].

61 William M. Barnard, 44 Rad. Reg. 2d (P \& F) 525, 527 (1978).

62 Amendment of Section 73.3597, supra note 60, at 974 .

631982 Policy Statement, supra note 54, at 849 n.1. This represents a change from the Commission's 1978 Policy Statement which specified that "minorities include those of Black, Hispanic Surnamed, American Eskimo, Aleut, American Indian and Asiatic American extraction." 1978 Policy Statement, supra note 12, at 980 n.8.

64 See 47 U.S.C. § 309(i)(3) (1982) ("The term 'minority group' includes Blacks, Hispanics, American Indians, Alaska Natives, Asians, and Pacific Islanders.").

65 Communications Amendments Act of 1982, Pub. L. No. 97-259, 96 Stat. 1087 (1982). 
agement and Budget Statistical Policy Directive No. 15, 'Race and Ethnic Standards for Federal Statistics and Administrative Reporting,' be utilized for guidance with regard to any dispute as to an individual's membership in a named group."66 The OMB Directive provides definitions of the various minority-group designations. ${ }^{67}$ In at least one case, the Commission has subsequently modified its definitions for purposes of determining eligibility for tax certificates to conform with these OMB standards. ${ }^{68}$ It is reasonable to expect that the Commission would rely on the definitions in the OMB Directive to resolve any future questions about who is a qualified minority buyer for purposes of the program.

\section{E. Other Program Details}

Since the adoption of the 1982 Policy Statement, sellers of broadcast stations have not been the only persons eligible to receive tax

66 H. Conf. ReP. No. 765, 97th Cong., 2d Sess. 45 (1982), reprinted in 1982 U.S. Code Cong. \& Admin. News 2261, 2289.

67 The Directive, which was formally issued by the Office of Management and Budget in May, 1977, is reproduced and its development is explained in Wallman \& Hodgdon, Race and Ethnic Standards for Federal Statistics and Administrative Reporting, 7710 Statistical REP. 450 (1977). It provides the following definitions:

1. American Indian or Alaskan Native. A person having origins in any of the original peoples of North America, and who maintains cultural identification through tribal affiliation or community recognition.

2. Asian or Pacific Islander. A person having origins in any of the original peoples of the Far East, Sourheast Asia, the Indian subcontinent, or the Pacific Islands. This area includes, for example, China, India, Japan, Korea, the Philippine Islands, and Samoa.

3. Black. A person having origins in any of the black racial groups of Africa.

4. Hispanic. A person of Mexican, Puerto Rican, Cuban, Central or South American or other Spanish culture or origin, regardless of race.

5. White. A person having origins in any of the original peoples of Europe, North Africa, or the Middle East.

Id. at 451 .

68 See Storer Broadcasting, 87 F.C.C.2d 190 (1981). The Commission issued tax certificates for assignment of licenses to Adolfo Liberman and his sons and to Oscar Luis Kramer. Both presented evidence that they are Spanish-speaking and are identified with the Hispanic communities in Florida. The Commission stated: "[W]e conclude that the category 'Hispanic Surnamed' as used in the [1978] Policy Statement includes those persons who are, in fact, Hispanic by origin or culture and identification, but not necessarily "Hispanic Surnamed." The Commission noted that it had previously adopted the OMB standards in defining racial and ethnic categories to be used by broadcast licensees in their required annual employment reports. See also FCC Form 395-B, Broadcast Station Annual Employment Report 1988 (and instructions) (using OMB racial categories), reprinted in [Finding Aids, Master Index, Forms] Rad. Reg. 2d (P \& F) 98:395B-1, 98:395B-4 (1988). 
certificates. At the suggestion of its Advisory Committee on Alternative Financing for Minority Opportunities in Telecommunications, the Commission also announced it would consider issuing tax certificates to persons who provide capital to help establish minority-controlled broadcasting enterprises. To qualify, the investment must be "start up" financing made before or within one year after the minority business receives a broadcast license. A certificate may be granted to the investor at the time she subsequently sells her interest in the minority business, deferring taxation of any capital gain realized by the investor. The broadcast enterprise in which such an investment was made must have been minority-controlled to begin with and must continue to be minority-controlled after the sale of equity by the investor who seeks a tax certificate. ${ }^{69}$ This expansion of the program, like the original version, was justified by the Commission's continuing goal of increasing programming diversity by increasing the number of minority-controlled stations. ${ }^{70}$

The types of property that may be sold to qualify for a tax certificate have been expanded beyond radio and TV stations. The Commission decided, for example, that section 1071 could be extended to reach cable TV systems and television networks. ${ }^{71}$ There have been proposals to include cellular telephone systems as well, but the Commission declined to take that step. ${ }^{72}$

This, then, is an outline of the tax certificate program as the Commission has developed and implemented it to date. But is it a sound program? Is it legally proper, and is it well-designed? Examination of these issues begins with a consideration of statutory authority and constitutionality.

\section{Statutory AUthority}

The tax certificate program for minority ownership was created by the Commission entirely on its own initiative, without direction from Congress, using general statutory authority that had been

69 See 1982 Policy Statement, supra note 54, at 856-57 \& n.39.

70 "The use of tax certificates as creative financing tools will facilitate significantly minority entrepreneurs' access to necessary financing, thus effectuating the important policy of promoting minority ownership ...." Id. at 857 .

71 See Policy Statement on Minority Ownership of Cable Television Facilities, 52 Rad. Reg. 2d (P \& F) 1469, 1472 (1982).

72 See Cellular Mobile Sys. of Tampa, 98 F.C.C.2d 231, 234-35 (1984) (declining to grant any minority preference in cellular telephone licensing because a cellular service is a common carrier, not a mass media service, and therefore the licensee has no control over the content of radio communications, making the diversification justification inapplicable). 
granted for entirely different purposes more than thirty years before. ${ }^{73}$ In 1987, Congress finally gave its blessing to the program, not through direct authorization, but by forbidding the Commission to eliminate or reconsider the existing program. Although the will of Congress is no longer in doubt, Congress did not make its wishes explicit until a federal appeals court decision and a change in philosophy within the Commission itself placed the program in jeopardy. ${ }^{74}$ The history of the prograrn provides an interesting study of the extensive policy-making power of an administrative agency operating with the support of the courts, but also illustrates the vulnerability of such policy initiatives.

\section{A. Making the Policy}

The key policy underlying the tax certificate program is that the Commission should give members of racial minority groups special advantages in obtaining control of broadcast licenses. The policy favoring minority owners dates from 1973, when the Court of Appeals for the District of Columbia Circuit reversed the Commission's previous stand and announced in $T V$ 9, Inc. v. FCC ${ }^{75}$ that awarding "merit" to applicants for minority-group involvement in ownership and management: was not only permissible, but required by statute. The Review Board, in an opinion accepted by the Commission, had taken the view that "the "Communications Act, like the Constitution, is color blind. What the Communications Act demands is service to the public in the programming of the station and that factor alone must control the licensing processes, not the race, color or creed of an applicant." "76 The appeals court responded:

To say that the Communications Act, like the Constitution, is color blind, does not fully describe the breadth of the public interest criterion embodied in the Act. Color blindness in the protection of the rights of individuals under the laws does not foreclose consideration of stock ownership by members of a Black minority where the Commission is comparing the qualifications of applicants for broadcasting rights .... $77^{7}$

This stand was controversial in 1973. Four judges wanted to rehear

73 See supra notes 38-48 and accompanying text.

74 See infra notes 83-98 and accompanying text.

75495 F.2d 929 (D.C. Cir. 1973), cert. denied, 419 U.S. 986 (1974).

76 Id. at 936 (quoting Mid-Florida Television Corp., 33 F.C.C.2d 1, 17 (Rev. Bd.), aff'd, 37 F.C.C.2d 559 (Commission 1972) (citation omitted)).

77 Id. 
the case en banc to consider whether the panel's interpretation of the statute amounted to unconstitutional race discrimination. ${ }^{78}$ The decision, however, stood. The court's interpretation of the statute has since been reaffirmed and clarified by the same court in West Michigan Broadcasting Co. v. FCC, ${ }^{79}$ holding that the Commission could give merit to a minority applicant regardless of whether or not there was a substantial minority-group population in the city of license. Increased media ownership by minority-group persons anywhere, the court decided, should conclusively be presumed to advance the public interest. ${ }^{80}$

The Commission used the TV 9 interpretation of the Communications Act mandate and combined it with the general tax certificate authority contained in section 1071 of the Internal Revenue Code ${ }^{81}$ to create another tool in the service of minority ownership policythe tax certificate program. ${ }^{82}$

\section{B. A Hint of Congressional Policy}

In 1982, after four years of the tax certificate program and two years before West Michigan, Congress first signalled its approval of the general policy of giving advantages to minority persons in gaining control of broadcast licenses. Section 115 of the Communications Amendments Act of $1982^{83}$ authorized the Commission to

78 See id. at 942 (statement of Wilkey, J.) ("I think this country and its courts long ago reached the conclusion that race could not be a merit or demerit and that any decision based on race as a factor was constitutionally wrong, morally wrong, and dangerous.").

79735 F.2d 601 (D.C. Cir. 1984), cert. denied, 470 U.S. 1027 (1985).

80 See id. at 608-12. In TV 9, the court noted that there was a substantial black population in the Orlando, Florida area where the station was located and that none of the other media in the area were black-owned. However, the West Michigan court concluded that those factors were not necessary to the $T V 9$ result:

[G]iven the extreme underrepresentation of minorities in ownership of the broadcast mass media, the rationale of promoting program diversity - a rationale that is derived from the First Amendment and at the heart of the Communications Act - supports granting positive weight to minority ownership as a factor in comparative broadcast hearings where that ownership is accompanied by participation in station affairs.

West Michigan, 735 F.2d at 610 (citation omitted); cf. Garrett v. FCC, 513 F.2d 1056 (D.C. Cir. 1975) (holding that where two daytime-only radio stations competed for authority to operate at night, the fact that one station was black-owned should have been considered).

8126 U.S.C. § 1071 (1972).

82 See supra notes $38-48$ and accompanying text.

83 Pub. L. No. 97-259, § 115, 96 Stat. 1087, 1094-95 (codified at 47 U.S.C. $\S 309$ (i) (1982)). 
choose by lottery among competing qualified applicants for certain licenses as an alternative to lengthy comparative proceedings. However, in using such a procedure, Congress required that:

significant preferences will be granted to applicants or groups of applicants, the grant to which of the license or permit would increase the diversification of ownership of the media of mass communications. To further diversify the ownership of the media of mass communications, an additional significant preference shall be granted to any applicant controlled by a member or members of a minority group. ${ }^{84}$

The legislative history of this provision notes with approval the Commission's continuing minority-group enhancement policy and diversity of viewpoint rationale, and clearly shows that Congress wanted to ensure that a similar minority preference was applied in any random selection licensing system. ${ }^{85}$

\section{The Policy Starts to Unravel}

The combination of $T V$ 9, West Michigan, and the 1982 legislation seemed to settle the question of statutory authority for the tax certificate program. Then came Steele v. FCC. ${ }^{86}$ In Steele, the Commission had chosen a female over a male applicant in a comparative license proceeding, and the Review Board stated that the " $100 \%$ female integration [of the winning applicant] is decisively important." "87 The Commission thus expanded its minority-preference policy to include women as well. In a split decision, the court of appeals held that the Commission exceeded its statutory authority in attempting to create a preference for female applicants. ${ }^{88}$ The opinion and judgment were later vacated, and the case was remanded to the Commission at the Commission's request. ${ }^{89}$ However, the reasoning employed in the original opinion raised substantial concerns about statutory authority that may be more important in the tax certificate program than they were in the comparative enhancement credit that was before the court.

8447 U.S.C. $\S 309$ (i)(3)(A) (1982).

85 H. Conf. ReP. No. 765, 97th Cong., 2d Sess. 40, reprinted in 1982 U.S. CodE Cong. \& ADMIN. NEws 2261, 2284.

86770 F.2d 1192 (D.C. Cir. 1985).

87 Id. at 1194 (court's emphasis) (quoting Review Board opinion below which was affirmed by the Commission without comment).

88 Id. at 1199.

89 See infra note 97 and accompanying text. 
In the opinion, Judge $\mathrm{Tamm}^{90}$ attacked the assumption that diversity of ownership is likely to produce diversity of program content. He argued:

There is no reason to assume, for example, that an Italian station owner would primarily program Italian operas or would eschew Wagner in favor of Verdi. Similarly, it is questionable whether a black station owner would program soul rather than classical music or that he would manifest a distinctively "black" editorial viewpoint. Indeed, to make such an assumption concerning an individual's tastes and viewpoints would seem to us mere indulgence in the most simplistic kind of ethnic stereotyping. ${ }^{91}$

He suggested an alternative assumption: that station owners are most likely to respond to a profit motive and to design programming they believe will appeal to their available audience, thus maximizing ratings and advertising revenue. ${ }^{92}$ Judge Tamm found the Commission's assumption "so questionable as a matter of fact and so offensive as a matter of principle" that it exceeded the agency's discretion under the statute. ${ }^{93} \mathrm{He}$ concluded: "a mandate to serve the public interest is not a license to conduct experiments in social engineering conceived seemingly by whim and rationalized by conclusory dicta." 94

Under Judge Tamm's analysis, the race or sex of a station owner should make no difference, and the public interest in programming diversity should not justify a policy of favoring women or minoritygroup members. ${ }^{95}$ This analysis would lead us back to a color- and gender-blind diversification policy of the sort the Commission used for many years before $T V 9$.

The Steele opinion raised interesting questions, but it conflicted with the established case law and the policy direction of the Commission up to 1985. It may therefore be viewed simply as an aberration. Accordingly, it has been severely criticized. ${ }^{96}$ Nevertheless, the

90 Judge Tamm joined in one of the published statements questioning the TV 9 decision. See TV 9, 495 F.2d at 942.

91 Steele, 770 F.2d at 1198.

92 See id. at 1198-99.

$93 \mathrm{Id}$. at 1199.

94 Id.

95 However, a policy of favoring non-media-owners over current media owners, that is, ownership diversity without regard to group affiliation of individual applicants, might still be justified. $I d$. at 1195 .

96 See generally Comment, The Female Merit Policy in Steele v. FCC: "A Whim Leading to a Beller World?", 37 AM. U.L. Rev. 379, 396-415 (1988) (arguing that the Steele decision and FCC brief on rehearing were incorrect). 
Commission seized upon it and requested a remand, committing itself to reexamine not just female preference, but all its racial preference programs as well. ${ }^{97}$ The FCC issued a notice of inquiry that requested public comments on the constitutionality and effectiveness of the race and gender preference programs. ${ }^{98}$ The inquiry was cut short, however, by Congressional intervention.

\section{Congress Stops the Debate}

When the instability of the Commission's independent policy initiative became apparent, Congress was motivated to act. A December 22, 1987 supplemental appropriation ${ }^{99}$ included a rider prohibiting the Commission from changing or reexamining any of its race or gender preference programs, including the tax certificate

97 Technically, the Court of A.ppeals first vacated the panel opinion en banc and requested new briefs on the statutory authority and constitutionality of gender preference. The Commission's brief questioned the legality of its own policy and requested a remand to re-examine the programs. The court ordered the remand on October 9, 1986. See Reexamination of the Commission's Comparative Licensing, Distress Sales and Tax Certificate Policies Premised on Racial, Ethnic or Gender Classifications, I F.C.C. Rcd. 1315, 1316 (Dec. 30, 1986) [hereinafter Reexamination].

The Commission's actions were criticized as a significant retreat from its previous support of affirmative action. See Minority-Owned Broadcast Stations: Hearing Before the Subcomm. on Telecommunications, Consumer Protection, and Finance of the Comm. on Energy and Commerce, 99th Cong., 2d Sess. 1-3 (1986) (statement of Rep. Collins) ("[T]his is an attempt on the part of the current Commission to abolish the credit given to minority and female applicants in comparative hearings. There is nothing that I have seen or heard to date which could justify such a policy switch."); Brown (former FCC Commissioner), The FCC's New Threat to Minority Preferences, Washington Post, Sept. 26, 1986, at A-27, col. 4 ("The decision of the Federal Communications Commission to repudiate its longstanding support for increased minority involvement in broadcasting is at best an unwitting insult to the aspirations of minority Americans. The Commission is trying to hide that fact under a cloak of constitutional arguments.").

98 See Re-examination, supra note 97, at 1317-18. The Commission explained its concerns as follows:

[T] he purpose behind each of these policies has been to expand program diversity. We find program diversity [to be a] compelling governmental interest within the Commission's authority. Although we do not interpret the Supreme Court opinions to preclude consideration of race or gender in the licensing process under all circumstances, we do read these cases to mean that the use of minority/gender status must include a determination of whether their use is necessary and narrowly tailored to achieve their goals. . . . To this end, we seek to determine whether there is a nexus between minority/female ownership and viewpoint diversity, and whether such ownership is necessary to achieve this goal.

Id. at 1317.

99 Act of Dec. 22, 1987, Pub. L. No. 100-202, 101 Stat. 1329. 
program. ${ }^{100}$ In obedience to this enactment, the Commission closed its inquiry ${ }^{101}$ and reaffirmed its grant of the station license to the female applicant in the Steele case. ${ }^{102}$ There have been no further proceedings in the appeals court.

\section{E. Conclusion}

Congress has answered the statutory authority question by effectively ratifying the Commission's interpretation of the public interest standard and adopting a legal presumption that minority ownership produces more diverse programming that better serves the public interest. ${ }^{103}$ However, Judge Tamm's logical objections to the reasoning remain. The diversity presumption may be justified in the context of comparative licensing, since the Commission requires integration of the credited minority-group ownership into daily management. The tax certificate program is more problematic because the minority owner can be an absentee owner or a diffused aggrega-

100 The provision states:

[N]one of the funds appropriated by this Act shall be used to repeal, to retroactively apply changes in, or to continue a reexamination of, the policies of the Federal Communications Commission with respect to comparative licensing, distress sales and tax certificates granted under 26 U.S.C. 1071 , to expand minority and women ownership of broadcasting licenses, including those established in Statement of Policy on Minority Ownership of Broadcast Facilities, 68 F.C.C. 2d 979 and 69 F.C.C. 2d 1591, as amended 52 R.R. 2d 1313 (1982) and Mid-Florida Television Corp., 60 F.C.C.2d, 607 (Rev. Bd. 1978) which were effective prior to September 12, $1986 \ldots$.

Id. at 1329-31.

Similar language contained in a bill that was designed to codify broadcasters' license renewal expectancies had been considered in committee earlier in the session. See Broadcasting Improvements, 1987: Hearings on S. 1277 Before the Senate Comm. on Commerce, Science, and Transp., 100th Cong., 1st Sess. II, § 402 (1987). The bill died after facing broadcasters' resistance to the compromises incorporated in the license renewal scheme. See Broadcasters Balk at Quid Pro Quo for Two-Step Renewal, BroadcaSTING, July 27, 1987, at 88 ("[B]roadcaster organizations for the most part were opposed. There are many within the industry who feel the trade-offs in the bill are too high.").

101 See Reexamination of the Commission's Comparative Licensing, Distress Sales and Tax Certificate Policies Premised on Racial, Ethnic or Gender Classifications, 3 F.C.C. Rcd. 766 (1988).

102 See Cannon's Point Broadcasting Co., 3 F.C.C. Rcd. 864 (1988).

103 The District of Columbia Circuit recently concluded that the closely analogous minority ownership distress sale policy, see supra note 14 and accompanying text, was also within the Commission's statutory authority, since Congress has indicated its approval of minority preferences in station licensing. See Shurberg Broadcasting of Hartford, Inc. v. FCC, 876 F.2d 902, 909-10 (D.C. Cir. 1989). 
tion of many owners, none of whom controls daily operations. Thus, minority ownership may not change or diversify the programming that the public receives, weakening the Commission's public interest justification. $^{104}$

\section{Constitutionality}

Although the tax certificate program is now firmly rooted in congressionally-determined policy as a statutory matter, that does not resolve the potential constitutional objections. To date, the constitutionality of the program has never been adjudicated, but the Supreme Court may provide an answer this year. On January 8, 1990 , the Court granted certiorari in cases that squarely present the constitutionality of both of the racial preference programs that are companions of the Commission's tax certificate program. Metro Broadcasting Inc. v. FCC ${ }^{105}$ is an appeal of a losing applicant in a comparative license proceeding in which the Court of Appeals for the District of Columbia Circuit upheld giving merit to a rival minoritycontrolled applicant. Astroline Communications Co. L.P. v. Shurberg Broadcasting of Hartford Inc. ${ }^{106}$ is an appeal by a minority-controlled assignee who purchased a television station at reduced price under the distress sale policy only to have the transaction rejected by another panel of the Court of Appeals for the District of Columbia Circuit in a decision that held the distress sale program unconstitutional. The rest of this Part considers the constitutionally important features of the tax certificate program and the case law which, except as noted, bear equally on both tax certificates and the companion programs which have been presented to the Court for review.

The essence of the tax certificate program is that it awards or denies tax deferral to the seller of a broadcasting station depending on the race or ethnic identity of the assignee. ${ }^{107}$ The government does not directly distribute benefits based on the race of recipients. Instead, the FCC program has created an economic incentive to

104 This issue is reconsidered infra notes 195-200.

105 Winter Park Communications Inc. v. FCC, 873 F.2d 347 (D.C. Cir. 1989), cert. granted sub nom. Metro Broadcasting Inc. v. FCC, 58 U.S.L.W. 3417 (U.S. Jan. 9, 1990) (No. 89-453).

106 Shurberg Broadcasting of Hartford Inc. v. FCC, 876 F.2d 902 (D.C. Cir. 1989), cert. granted sub nom. Astroline Communications Co. L.P. v. Shurberg Broadcasting of Hartford, Inc., 58 U.S.L.W. 3417 (U.S. Jan. 9, 1990) (No. 89-700).

107 The program also makes tax certificates available to investors providing "start-up" financing for minority-owned stations. See 1982 Policy Statement, supra note 54 , at $855-58$. 
encourage broadcast licensees to discriminate in favor of members of certain racial and ethnic groups when the licensees negotiate to sell broadcast properties. Conversely, the program denies the tax benefit to licensees who choose to sell to entities that are not minority-owned. From the perspective of potential buyers of broadcast stations, the program advantages minority purchasers. Sellers concerned about capital gains tax will tend to seek minority-owned buyers and discount the bids of non-minority-owned bidders.

The program clearly constitutes state action using racial classifications. That it operates indirectly through tax incentives rather than directly as a spending program should not make a difference constitutionally. ${ }^{108}$ If it did, the government could readily circumvent the due process guarantee of the fifth amendment ${ }^{109}$ by creating economic incentives for private persons to carry out the racial discrimination that the government itself is forbidden to practice.

The Constitution prohibits the government from using racial classifications, even to benefit an historically disadvantaged group, unless those classifications are necessary to protect compelling and legitimate state interests. ${ }^{110}$ What constitutes a compelling state

108 See Comment, Tax Incentives as State Action, 122 U. PA. L. Rev. 414, 449 (1973) (arguing that tax provisions intended as social and economic incentives should be analyzed to determine the applicability of constitutional restrictions on state action); $c f$. McGlotten v. Connally, 338 F. Supp. 448, 459 (D.D.C. 1972) (threejudge panel) (holding tax exemptions for fraternal organizations to be state action invoking fifth amendment scrutiny).

109 Courts generally have assumed that the due process clause of the fifth amendment imposes restrictions on actions of the federal government equivalent to those that the equal protection clause of the fourteenth amendment imposes upon the states. See Frontiero v. Richardson, 411 U.S. 677, 680 n.5 (1973) ("[W]hile the Fifth Amendment contains no equal protection clause, it does forbid discrimination that is "so unjustifiable as to be violative of due process." "(quoting Schneider v. Rusk, 377 U.S. 163, 168 (1964))); Bolling v. Sharpe, 347 U.S. 497, 500 (1954) ("In view of our decision [in Brown v. Board of Educ., 347 U.S. 483 (1954)] that the Constitution prohibits the states from maintaining racially segregated public schools, it would be unthinkable that the same Constitution would impose a lesser duty on the Federal Government.").

110 The Supreme Court's affirmative action cases emphasize this principle. See, e.g., City of Richmond v. J.A. Croson Co., 109 S. Ct. 706, 727 (1989) (O'Connor, J., opinion of the Court) ("[T] apportioning public contracting opportunities on the basis of race."); Wygant $v$. Jackson Bd. of Educ., 476 U.S. 267, 274 (1986) (Powell, J., plurality opinion) ("We must decide whether the layoff provision is supported by a compelling state purpose and whether the means chosen to accomplish that purpose are narrowly tailored."); Fullilove v. Klutznick, 448 U.S. 448, 472 (1980) (Burger, C.J., plurality opinion) ("A program that employs racial or ethnic criteria, even in a remedial context, calls for close examination ...."); Regents of the Univ. of Cal. v. Bakke, 438 U.S. 265, 299 (1978) (Powell, J.) (holding that an individual harmed by racial classification is always 
interest, whether a particular racial classification is necessary to protect the interest, and whether a given program is sufficiently narrowly drawn to achieve that goal, remain subject to considerable dispute.

Constitutional limits on affirmative action remain uncertain largely because the cases have severely splintered the Supreme Court. City of Richmond v. J.A. Croson Co., decided in 1989, was the first constitutional affirmative action case to produce any sort of majority opinion. ${ }^{111}$ Application of the affirmative action decisions to the tax certificate progran is particularly difficult because the program has always been justified by the general public interest and first amendment values, ${ }^{112}$ while the decided cases have focused on past racial discrimination as the underlying factor providing justification for racial classifications. ${ }^{13}$ Based on the Court's recent analytical approaches, the tax certificate program probably would not survive constitutional scrutiny as it is currently presented - that is, as a program designed and adopted by an administrative agency with a mandate only to regulate communications in the public interest. At the

"entitled to a judicial determination that the burden he is asked to bear on that basis is precisely tailored to serve a compelling governmental interest"); Korematsu v. United States, 323 U.S. 214, 216 (1944) (Black, J.) ("[A]ll legal restrictions which curtail the civil rights of a single racial group are immediately suspect. . . . [C]ourts must subject them to the most rigid scrutiny. Pressing public necessity may sometimes justify the existence of such restrictions .....").

A majority of the court now is of the view that there is only one standard of scrutiny for racial classification. It is strict, regardless of whether the classification appears to advantage or disadvantage a racial minority group. See City of Richmond, $109 \mathrm{~S}$. Ct. at 721 (O'Connor, J., joined by Rehnquist, C.J. and White and Kennedy, J.) ("Absent searching judicial inquiry into the justification for such race-based measures, there is simply no way of determining what classifications are 'benign' or 'remedial' and what classifications are in fact motivated by illegitimate notions of racial inferiority or simple racial politics."); id. at 735 (Scalia, J., concurring in judgment) ("[S]trict scrutiny must be applied to all governmental classification by race . ..."). This clear majority position is now acknowledged even by the Justices who have long argued that a less strict standard should apply in affirmative action cases. See id. at 752 (Marshall, J., joined by Brennan and Blackmun, JJ., dissenting) ("Today, for the first time, a majority of this Court has adopted strict scrutiny as its standard of Equal Protection Clause review of race-conscious remedial measures. This is an unwelcome development." (citation omitted)).

11 City of Richmond was a six to three decision, but only five Justices joined in Justice O'Connor's opinion, and that majority agreed on only part of her analysis. See 109 S. Ct. at 712.

112 See supra note 9 and accompanying text.

113 See, e.g., City of Richmond, $109 \mathrm{~S}$. Ct. at 720 (noting that the city could take affirmative action if it had participated in racial discrimination); Wygant, 476 U.S. at 274 (noting that a showing of governmental discrimination is needed to justify racial classifications). 
same time, Congress would appear to have the power to remove the constitutional cloud if it were to make appropriate findings of past discrimination and to explicitly reenact the program based on those findings.

\section{A. Compelling State Interest}

When the Commission adopted the tax certificate program, it stated that its purpose was to advance the public interest in diversity of broadcast programming and specifically to increase the expression of minority viewpoints. ${ }^{114}$ It declared that "diversified programming ... is a key objective not only of the Communications Act of 1934 but also of the First Amendment."115 The Commission cited the finding of its Minority Ownership Task Force that fewer than one percent of the commercial radio and television stations then operating in the United States were minority-controlled, and it concluded: " $[\mathrm{T}]$ he present lack of minority representation in the ownership of broadcast properties is a concern to us. We believe that diversification in the areas of programming and ownership-legitimate public interest objectives of this Commission-can be more fully developed through our encouragement of minority ownership of broadcast properties." 116

Viewpoint diversity, indeed, is the only justification the Commission has ever offered for the racial classification employed in the tax certificate program. ${ }^{117}$ The Court probably would not find this to be a compelling governmental interest. The Supreme Court's recent affirmative action decisions have focused instead on remedies of specific past racial discrimination as the interest that can justify racial classifications. ${ }^{118}$ The concept is derived from the school desegregation cases in which the courts ordered race-conscious remedies after

114 See 1978 Policy Statement, supra note 12, at 981.

$115 \mathrm{Id}$.

116 Id.

117 The same basic rationale was recited in the 1982 Policy Statement which broadened eligibility for tax certificates:

The Commission has traditionally considered the underrepresentation of minority points of view over the airwaves as detrimental to minorities and the general public. Accordingly, we have taken steps to enhance the ownership and participation of minorities in the media, with the intent of thereby increasing the diversity in the control of the media and thus diversity in the selection of available programming, benefitting the public and serving the principle of the First Amendment.

1982 Policy Statement, supra note 54, at 849-50 (footnotes omitted).

118 See supra note 110 and accompanying text. 
finding specifically that school authorities had practiced discrimination. ${ }^{119}$ Two current Justices, Rehnquist and Scalia, appear to take the view that only the remedying of past discrimination will justify a racial classification. ${ }^{120}$ Only Justice Stevens specifically accepts the idea that governmental interests other than remediation can justify racial classifications. ${ }^{121}$ Justice Stevens dissented in Wygant v. Jackson Board of Education ${ }^{122}$ because he thought the school board could "reasonably conclude that an integrated faculty will be able to provide benefits to the student body that could not be provided by an all-white, or nearly all-white, faculty." 123 He recognized a "rational and unquestionably legitimate basis" for a collective agreement that would protect minority teachers with less seniority from the effects of economic layoffs. ${ }^{124}$ The Court, however, ignored the educational purpose argument and decided that the school board's action was unconstitutional because the board did not have "convincing evidence" that there had been prior employment discrimination requiring remediation. ${ }^{125}$

An argument that the Commission's diversity interest indeed is compelling might be derived from Justice Powell's opinion in Bakke. Although the Court condemned the University of California's special medical school admission policy because it created a numerical quota for minority-group students, ${ }^{126}$ Justice Powell suggested that the medical school might have a compelling interest in creating a diverse

119 See, e.g., Swann v. Charlotte-Mecklenburg Bd. of Educ., 402 U.S. 1, 22-31 (1971) (upholding a remedial order involving racial quotas for schools, re-drawing of boundaries along racial lines, and busing for integration).

120 See City of Richmond v. J.A. Croson Co., 109 S. Ct. 706, 737 (1989) (Scalia, $\mathrm{J}$., concurring in judgment) ("In my view there is only one circumstance in which the States may act by race to 'undo the effects of past discrimination': where that is necessary to eliminate their own maintenance of a system of unlawful racial discrimination."); Fullilove v. Klulznick, 448 U.S. 448, 528 (1980) (Rehnquist, J., joining in dissent of Stewart, J.) ("Certainly, nothing in the Constitution gives Congress any greater authority to impose detriments on the basis of race than is afforded the Judicial Branch. And a judicial decree that imposes burdens on the basis of race can be upheld only where its sole purpose is to eradicate the actual effects of illegal race discrimination." (footnote omitted)).

121 See City of Richmond, 109 S. Ct. at $730 \mathrm{n} .1$ (Stevens, J., concurring in part and in judgment) ("I think it unfortunate that the Court in neither Wygant nor this case seems prepared to acknowledge that some race-based policy decisions may serve a legitimate public purpose.").

122476 U.S. 267 (1986).

123 Id. at 315 (Stevens, J., dissenting).

124 See id. at 315-16.

125 See id. at 277-78 (Powell, J., plurality opinion).

126 See Regents of the Univ. of Cal. v. Bakke, 438 U.S. 265, 319-20 (1978) (Powell, J., opinion of the Court). 
student body in order to foster intellectual give and take necessary to the educational process. ${ }^{127}$ Therefore, the use of race as one factor in a multifactor admissions policy aimed at creating diversity could be justified. ${ }^{128}$ In 1984, the District of Columbia Circuit used Justice Powell's reasoning and analogized that there was a compelling state interest in diversity of broadcast programming that would justify giving some credit to minority control of an applicant in a comparative licensing case. ${ }^{129}$ However, even if the analogy is valid, there is some doubt whether Justice Powell's 1978 dicta would carry a majority of the Court today. ${ }^{130}$ It should also be noted that unlike comparative merit, where race is but one of many factors weighing in a decision, in the tax certificate and distress sale programs, race is the sole factor that determines whether a governmental benefit is given or withheld.

The public interest invoked by the FCC in support of the tax certificate is also quite similar to the "role model" justification offered in Wygant-a reasonable and arguably "compelling" goal that is within the Commission's special area of competence to judge. ${ }^{131}$ The current Court, however, appears hostile to such justifications, ${ }^{132}$ and might not find the "diversification" interest sufficiently compelling.

\section{B. Narrowly Tailored}

Different views of compelling state interests lead to different standards for assessing the requirement that racial classifications be narrowly tailored to furthering compelling interests. If one justifies

127 See id. at $311-13$.

128 See id.

129 See West Mich. Broadcasting Co. v. FCC, 735 F.2d 601, 614-15 (D.C. Cir. 1984), cert denied, 470 U.S. 1027 (1985).

130 See Shurberg Broadcasting of Hartford, Inc. v. FCC, 876 F.2d 902, 919-21 (D.C. Cir. 1989), cert. granted sub nom. Astroline Communications Co. L.P. v. Shurberg Broadcasting of Hartford, Inc., 58 U.S.L.W. 3417 (U.S. Jan. 9, 1990) (No. 89-700) (questioning whether Powell's view in Bakke survives City of Richmond, and further suggesting that the FCC itself has undermined the diversity justification by relying on the market rather than regulation to protect the public's interest in diversity). But see Comment, The Constitutionality of the FCC's Use of Race and Sex in the Granting of Broadcast Licenses, 83 Nw. U. L. REv. 665 (1989) (arguing that diversity is a compelling interest and that comparative merit-which may be distinguishable from tax certificatesremains constitutionally permissible).

131 See supra notes 27-32 and accompanying text; cf. Wygant, 476 U.S. at 315 (Stevens, J., dissenting) (" $[\mathrm{I}] \mathrm{t}$ is quite obvious that a school board may reasonably conclude that an integrated faculty will be able to provide benefits to the student body that could not be provided by an all-white, or nearly all-white, faculty.").

132 See supra notes $118-20$ and accompanying text. 
the classification as remediation of past racial discrimination, then the remedy must be narrowly drawn to benefit the class that suffered the discrimination. It must not extend any farther than the constitutional violation that is being remedied, and it must not impose disproportionate burdens on the members of the racial majority who are disadvantaged. This standard implies that "a generalized assertion that there has been past discrimination in an entire industry provides no guidance for a legislative body to determine the precise scope of the injury it seeks to remedy." 133 Showing there is a statistical disparity between the percentage of a racial group in the population and its participation in a particular occupation or industry is not probative of whether there has been discrimination unless no other, nondiscriminatory factors can explain the disparity. ${ }^{134}$ There must be a "strong basis in evidence" of past discrimination to prove the need for remedial action. ${ }^{135}$ The finding of past discrimination must be specific to the area within which the remedy is to be applied, ${ }^{136}$ and the finding must be specific to the particular racial groups that stand to benefit. ${ }^{137}$ The majority's discussion in City of Richmond appears to support Justice Stevens' conclusion that "[u]nless the legislature can identify both the particular victims and the particular perpetrators of past discrimination, which is precisely what a court does when it makes findings of fact and conclusions of law, a remedial justification for race-based legislation will almost certainly sweep too broadly." 138

If, alternatively, one adopts Justice Stevens' previously expressed view that a racial classification may be used to serve a legitimate public purpose without being remedial, then the "narrowly tailored" requirement demands only that the legitimate purpose cannot be achieved without a racial classification and "that public interest, and the manner in which it is pursued, justifies any

133 City of Richmond, 109 S. Ct. at 723; cf. Wygant, 476 U.S. at 274 (Powell, J., plurality opinion) ("This Court never has held that societal discrimination alone is sufficient to justify a racial classification.").

134 See City of Richmond, 109 S. Ct. at 725 ("Reliance on the disparity between the number of prime contracts awarded to minority firms and the minority population of the city of Richmond is . . misplaced.").

135 See id. at 724 (quoting Wygant, 476 U.S. at 277).

136 See id. at 726-27 (noting that the finding of discrimination on a national scale would not support finding discrimination in Richmond).

137 See id. at 727-28 ("The random inclusion of racial groups that, as a practical matter, may never have suffered from discrimination in the construction industry in Richmond, suggests that perhaps the city's purpose was not in fact to remedy past discrimination.").

138 Id. at $730 \mathrm{n} .1$ (Stevens, J., concurring in part and in the judgment). 
adverse effects on the disadvantaged [that is, the majority] group." 139

Under the remedial justification theory, which appears now to be the majority view, the tax certificate program would fail the "narrowly tailored" standard. The Commission did not even attempt to present evidence that it, or anyone else, had specifically discriminated against racial minorities in licensing or sales of broadcast properties. ${ }^{140}$ Its finding that minorities own a smaller percentage of stations than their percentage in the population ${ }^{141}$ would be insufficient just as the smaller percentage of minority-owned construction companies was insufficient in City of Richmond. ${ }^{142}$ And its lumping together of "American Indians or Alaskan Natives, Asians and Pacific Islanders, Blacks and Hispanics" 143 as one class to receive an identical benefit would be taken as an indication that the purpose of the program is not remedial or that the remedy is not narrowly tailored to match the constitutional wrong.

In his opinion in Shurberg Broadcasting, Judge Silberman pointed to several specific ways in which the distress sale program is not narrowly tailored to remedy the putative wrong. The amount of benefit to a minority-purchasers is a function of factors that are determined by the market and are not tied to the degree of disadvantage that is to be redressed. There is no requirement that beneficiaries of the program show they are in fact disadvantaged and in need of a government benefit. ${ }^{144}$ Nor has the FCC shown that it cannot achieve increased diversity with racially-neutral programs and that a racebased remedy is essential. ${ }^{145} \mathrm{He}$ also concludes that the distress sale policy is not narrowly tailored to the goal of programming diversity because it was not shown that minority ownership would lead to

139 Wygant, 476 U.S. at 313 (Stevens, J., dissenting) (footnote omitted).

140 Language in a 1982 Congressional report suggests that the small number of minority-owned stations is attributable to general societal discrimination rather than any discrimination specific to the broadcasting industry. See H.R. CoNF. Rep. No. 765, 97th Cong., 2d Sess. 43 (1982) ("[T]he effects of past ineqities stemming from racial and ethnic discrimination have resulted in a severe underrepresentation of minorities in the media of mass communications, as it has adversely affected their participation in other sectors of the economy as well.").

The court in Shurberg Broadcasting, 876 F.2d at 914-15, concluded this language was not evidence of past discrimination that could support the racial classification of the distress sale policy.

141 See supra text accompanying note 116.

142 See supra note 134 and accompanying text.

143 See supra text áccompanying note 63.

144 See Shurberg Broadcasting, 876 F.2d at 916 . These objections are discussed in more detail infra at notes 178-84 and accompanying text.

145 See Shurberg Broadcasting, 876 F.2d at 917. 
more diverse programming. Assuming that minority owners would program differently than non-minority owners, he suggested, is an impermissible form of racial stereotyping. ${ }^{146}$ All these objections are equally applicable to the tax certificate program, supporting the conclusion that it is not narrowly tailored.

The program, however, probably would be found "narrowly tailored" under Justice Stevens' legitimate public purpose test. The Commission found specifically that its previous measures had not been effective in producing substantial gains in minority ownership. ${ }^{147}$ Because the principal avenue of entry into the broadcasting industry today, at least in large cities, is the purchase of existing stations, ${ }^{148}$ the Commission could conclude that providing an incentive for present owners to sell to minorities is essential to achievement of its legitimate purpose. Justice Stevens was prepared to find that even discriminatory layoffs of white teachers in Jackson, Michigan, was not an excessive adverse effect in light of the school board's purpose. ${ }^{149}$ In comparison, the disappointment and speculative injury suffered by a potential station purchaser who loses out to a minority person in bidding on a specific property because of the program seems a rather minor adverse effect. Other adverse effects, such as the burden on all taxpayers of the cost of the tax benefit, while not insignificant, probably would not be fatal to the program under Justice Stevens' analysis.

\section{Federal Versus State Competence}

One of the most puzzling aspects of the affirmative action decisions is the seeming inconsistency of approach between Fullilove, upholding a federal affirmative action statute, and City of Richmond, Wygant, and Bakke, which all struck down state or local affirmative action programs. Chief Justice Burger purported to apply a form of

146 See id. at 921-23.

147 See supra note 38 and accompanying text.

148 Sales of existing stations are much more frequent than issuance of new licenses. For example, from 1978 to 1987, the Commission approved 7,521 assignments and transfers of radio stations, and 616 such transactions involving commercial television stations. Set Broadcasting, Feb. 8, 1988, at 62. This means that on the average, two out of every three commercial radio stations and six out of every ten commercial television stations changed hands during the ten-year period. See Broadcasting, Oct. 17, 1988, at 10 (showing 9,031 commercial radio stations and 1,049 commercial television stations operating as of that date).

149 See Wygant, 476 U.S. at \$15-16 (Stevens, J., dissenting). For a complete discussion, see supra notes $122-25$ and accompanying text. 
strict scrutiny in Fullilove, ${ }^{150}$ but in fact he showed great deference to Congress, ${ }^{151}$ and bent over backwards to find something that could pass as "evidence" on which Congress could base "findings" that there had been industry-wide discrimination in the construction industry that required remediation. ${ }^{152}$ The approach resembles the minimal "rational basis" review afforded to classifications of economic or social regulation measures not involving race. ${ }^{153}$ In City of Richmond, the Court worked to distinguish Fullilove and limit its holding to acts of Congress. The Court grudgingly acknowledged Fullilove as precedent, but showed no enthusiasm for it. Justice Kennedy was most reluctant, implying that he might reexamine Fullilove's holding if the issue were to be presented again. ${ }^{154}$ But in the process of distinguishing, the Court appears to recognize a significant difference between federal and state government racial classifications or, perhaps, between congressionally created classifications and those created by any other entity. Federal or congressional classifications appear to get much less rigid scrutiny. ${ }^{155}$

150 "A program that employs racial or ethnic criteria, even in a remedial context, calls for close examination." Fullilove, 448 U.S. at 472 . However, the Chief Justice assiduously avoided using the words "strict scrutiny."

151 Id. at 483 ("It is fundamental that in no organ of government, state or federal, does there repose a more comprehensive remedial power than in the Congress, expressly charged by the Constitution [in section 5 of the fourteenth amendment] with competence and authority to enforce equal protection guarantees.").

152 Id. at 477-78 ("Congress had abundant evidence from which it could conclude that minority businesses have been denied effective participation in public contracting opportunities ... that perpetuated the effects of prior discrimination." (emphasis added)).

This contention is disputed by Justice Stevens, who pointed out there was no legislative history of the $10 \%$ minority set-aside in the public works bill and that the "abundant evidence" consisted of 3 paragraphs in a House Report that had been issued in connection with an entirely unrelated bill. He found Congress' entire decisionmaking process on the MBE provision insufficient to support a claim that it was necessary remedial legislation. See id. at 548-52 \& n.25 (Stevens, J., dissenting).

153 See, e.g., Railroad Retirement Bd. v. Fritz, 449 U.S. 166, 181 (1980) (Stevens, J., concurring) (finding "a correlation between the classification and . . . a legitimate purpose that we may reasonably presume to have motivated an impartial legislature" is sufficient to sustain inequality in allocation of retirement benefits); McGowan v. Maryland, 366 U.S. 420, 426 (1961) ("A statutory discrimination will not be set aside if any state of facts reasonably may be conceived to justify it.").

154 See Cily of Richmond, 109 S. Ct. at 734 (Kennedy, J., concurring in part and in the judgment) ("The process by which a law that is an equal protection violation when enacted by a State becomes transformed to an equal protection guarantee when enacted by Congress poses a difficult proposition for me; but as it is not before us, any reconsideration of that issue must await some further case.").

155 See id. at 717-19. Justice O'Connor wrote:

"Correctly viewed, $\S 5$ is a positive grant of legislative power authorizing 
Applying these principles to the tax certificate program, it is obvious the program is not a remedial measure enacted pursuant to Congress' supposed special competence under section five of the fourteenth amendment. Instead, it is a program devised by an administrative agency charged with regulation of the communication industries. ${ }^{156}$ The FCC arguably has no mandate or special competence to make findings that there has been racial discrimination that needs a remedy. As described above, the Commission did not even purport to make such a finding, nor has Congress, despite its apparent support for the program. ${ }^{157}$

The constitutionality of the tax certificate program therefore is doubtful under the Court's current approach in affirmative action cases. ${ }^{158}$ But at the same tirne, it is unlikely that any aggrieved party would succeed in overturning the program. Since Congress has

Congress to exercise its discretion in determining whether and what legislation is needed to secure the guarantees of the Fourteenth Amendment." ... The Civil War Amendments themselves worked a dramatic change in the balance between congressional and state power over matters of race. ... "They were intended to be, what they really are, limitations of the powers of the States and enlargements of the power of Congress."

Id. at 719 (quoting Katzenbach v. Morgan, 384 U.S. 641, 651 (1966) and Ex parte Virginia, 100 U.S. $339,345(1880)$ respectively).

Justice Scalia, who takes perhaps the narrowest view concerning justification for racial classifications, agreed that Congress has more power in this area than states. Id. at 736-37. He added: "The struggle for racial justice has historically been a struggle by the national society against oppression in the individual States." Id. at 736.

156 See supra notes 25-29 and accompanying text.

157 See supra notes 99-100 and accompanying text.

158 On a related issue, the Court of Appeals for the District of Columbia Circuit has held that affording comparative merit to minority ownership where the minority owners are integrated in station management does not violate equal protection. See West Mich. Broadcasting Co. v. FCC, 735 F.2d 601, 613-16 (D.C. Cir. 1984), cert. denied, 470 U.S. 1027 (1985). The Commission itself has expressed its opinion that the minority preference Congress enacted for use in connection with licensing lotteries would also be constitutional under Bakke and Fullilove. See Amendment of the Commission's Rules to Allow the Selection from Among Certain Competing Applications Using Random Selection or Lotteries Instead of Comparative Hearings, 93 F.C.C.2d 952, 974 (1983). Both authorities rely on the broad remedial authority of Congress announced in Fullilove, 448 U.S. at 490 , and the idea that only a plus factor is being applied in a licensing procedure that also uses other valid factors (comparative criteria or random selection) like the "Harvard plan" race-conscious admissions process that was approved in dicta by Justice Powell in Bakke. See 438 U.S. at 316-19.

However, the tax certificate program is distinguishable in two important ways: it has not been enacted by Congress in a process that involved "findings" of past discrimination and a determination of an appropriate remedy, and it uses race as the sole basis on which to grant or deny a tax benefit. 
twice indicated its support for measures to encourage minority ownership, ${ }^{159}$ it seems likely that any adverse court decision would induce Congress to pass legislation specifically finding that past racial discrimination has resulted in underrepresentation of minorities in broadcasting, and declaring that the program serves a compelling governmental interest in eliminating the effects of that discrimination (as well as serving the first amendment diversity interest). ${ }^{160}$ The Commission would thus be authorized to continue the program. Congress or the Commission itself could also make changes to fit the program more exactly to the identified governmental interests. In short, while the program does not appear to be covered by Fullilove as currently adopted, Congress could easily take action to bring it squarely under the Fullilove umbrella, putting its constitutionality beyond question, at least as long as Fullilove remains the law.

159 Congress expressed its wishes in the 1982 enactment requiring racial preference in licensing lotteries, see supra notes 83-85 and accompanying text, and in the 1987 supplemental appropriation rider (without legislative history) forbidding the Commission from changing its racial preference programs. See supra notes 99100 and accompanying text.

160 For an example of how Congress has covered the constitutional concerns about a racial classification program by creating appropriate language in the legislative history, see H. CoNF. REP. No. 765, 97th Cong., 2d Sess. 43-44, reprinted in 1982 U.S. CODE CONG. \& ADMin. NEws 2261, 2287-88, which was written to support the minority-applicant preference requirement in the license lottery provision of the Communications Amendments Act of 1982. The report states:

The Conferees find that the effects of past inequities stemming from racial and ethnic discrimination have resulted in a severe underrepresentation of minorities in the media of mass communications .... We note that the National Association of Broadcasters recently reported that of 8,748 commercial broadcast stations in existence in December, 1981, only 164, or less than two percent, were minority owned. Similarly, only 32 of the 1,386 noncommercial stations, slightly over two percent, were minority owned.

One means of remedying the past economic disadvantage to minorities which has limited their entry into ... the media of mass communications, while promoting the primary communications policy objective of achieving a greater diversification of the media of mass communications, is to provide that a significant preference be awarded to minority-controlled applicants in FCC licensing proceedings, for the media of mass communications. The narrowly-drawn preference scheme established in section 309(i), as it is amended by this legislation, is intended to achieve such a purpose.

Id. This language, while it might be discarded as conclusory dicta if invoked by a city council, is certainly as much as or more than the evidence the former Chief Justice found "abundant" in upholding the minority set-aside statute in Fullilove. 


\section{Tax Policy}

The FCC tax certificate program encourages sales of broadcast stations to minority-controlled businesses because it provides sellers an opportunity to defer payrnent of tax on capital gain income which otherwise would be recognized in the year in which the transaction occurs. The availability of this valuable tax-saving benefit gives the seller an incentive to choose a minority buyer over a non-minority buyer who is offering the same price. The seller may also be willing to sell to a minority person at a lower price than she would require from a non-minority buyer, since the minority buyer pays in dollars that are not subject to current tax. Both effects may occur together in a given case. ${ }^{161}$ Such a tax law provision, used to encourage a desired behavior rather than just to measure income and raise revenue, produces what has become known as a "tax expenditure."162 Examination of the program based on tax expenditure analysis points to several reasons why the program should not remain part of the income tax law. ${ }^{163}$

161 The Commission itself has recognized this analysis of the economic operation of a tax certificate:

[A] tax certificate enables the seller to defer taxes on capital gains, and thus provides an incentive to transfer a broadcast station to a minorityowned or controlled entity. Moreover, a 'tax certificate effectively subsidizes the bargaining position of minority entrepreneurs seeking to enter the telecommunications marketplace' because a 'tax certificate is effective only in those situations where the seller's capital gains savings exceeds the difference in purchase price offered by a non-minority and a minority purchaser.'

1982 Policy Statement, supra note 54, at 855 (quoting The Final Report of the Advisory Committee on Alternative Financing for Minority Opportunities in Telecommunications 8-9 (May 1982)).

162 "Tax expenditures" are statutorily defined as "revenue losses attributable to provisions of the Federal tax laws which allow a special exclusion, exemption, or deduction from gross income or which provide a special credit, a preferential rate of tax, or a deferral of tax liability ... ." Congressional Budget Act of 1974, 2 U.S.C. $\S 622(3)$ (1982).

163 For a general discussion of the tax expenditure concept and the disadvantages of tax expenditures from a policy standpoint, see S. SURREY \& P. McDaniel, Tax Expenditures 1-30 (1985).

Although the basics of tax expenditure analysis have become widely accepted, political reasons have deterred Congress from removing tax expenditures from the tax code. See Wolfman, Tax Expenditures: From Idea to Ideology (Book Review), 99 HARv. L. REv. 491, 497-98 (1985). 


\section{A. Objections to the Program as a Tax Expenditure}

\section{Inefficiency}

The program theoretically gives minority-controlled businesses the chance to obtain a "discount" in the purchase of broadcasting property. The discount might be any amount that does not exceed the seller's estimation of the net present value of the tax deferral benefit. However, there is a real incentive to participate only if the seller is better off with a tax certificate than without it, and that occurs only if the seller retains some portion of the tax savings for herself, passing only part of it along to the minority buyer in the form of a reduced price. The seller might retain the entire financial benefit if there are competing buyers.

When a certificate is issued, a minority person has acquired a station, but the non-minority seller has received a financial reward. Thus the program is to some extent "inefficient" because only some of the benefit dispensed by the government finds its way to the intended beneficiaries-that is, minority buyers. ${ }^{164}$

\section{Inability to Control Amount of the Benefit}

Another consequence of the indirect provision of the benefit through the seller-intermediary is that there is no rational relationship between the amount of benefit provided in a given case and the amount that would actually be needed to achieve the desired result. ${ }^{165}$ The amount that the government "spends"166 on each tax certificate, which is the amount of tax revenue that is indefinitely delayed, is measured by the amount of unrealized appreciation of the broadcast property that has occurred in the hands of the seller multiplied by the seller's income tax rate. The amount of benefit that is required for effectiveness is the smallest sum that would be sufficient to induce the seller to seek or select a minority buyer plus the small-

164 See S. Surrey \& P. MCDANiEl, supra note 163, at 83 ("[Some] tax expenditures are inefficient because they provide tax savings to middlemen who deliver the government assistance to the targeted beneficiaries. All such middlemen obtain a commission for their role.").

I65 See id. at 82-83 ("Some tax expenditures simply pay individuals for continuing to engage in their activities. ... Other tax expenditures are inefficient because the tax savings (subsidies) greatly exceed the value of the activity induced.").

166 The key insight of tax expenditure analysis is that "departures from the normal tax structure ... designed to favor a particular industry, activity, or class of persons," are functionally equivalent to direct government spending programs, even if they are implemented as an exclusion of income from tax, a deduction, or a deferral of tax liability. See id. at 3. 
est amount (if any) that the minority buyer requires in reduction from market price to enable (and induce) her to complete the transaction. The value of the tax certificate may be much more or much less than the amount required for effectiveness. If it is less, the buyer will probably not get the station and the program will be ineffective. If the tax certificate value is more than the amount required for effectiveness, a transaction probably will occur, but the program will be inefficient because its cost to the government exceeds the amount necessary to accomplish the desired result. ${ }^{167}$ The program can be effective and efficient only in the fortuitous and unlikely event that the value of the tax certificate to the seller is exactly equal to the amount of assistance needed to produce the desired transaction.

\section{Inability to Control Total Program Cost}

Like the amount of assistance dispensed in each particular case, the total amount spent under the program is also uncontrolled. Although the Commission set up the tax certificate program and established objective criteria for its operation, the Commission cannot control how many transactions will take place or what the program ultimately will cost.

The cost of the program is reflected in actual reduction of income tax receipts, which must be made up either by increasing the burden on other taxpayers, or by an equal increase in the federal budget deficit. The effect is indistinguishable from any direct government spending program. But the cost has no direct effect on the FCC budget or the amount of money the agency has to spend on its other programs. The amount to be spent need not be appropriated by Congress. ${ }^{168}$ Until this year, even the tax expenditure budgets prepared for Congress did not account for the program. ${ }^{169}$ The tax

167 It appears that officials at the FCC who review tax certificate requests could not consider the appropriateness of the dollar value of the assistance requested even if they were so inclined. This is because none of the documents required to be filed in connection with a request for consent to transfer a broadcast license provide any information about the amount of gain or loss the seller is realizing in the transaction. Nor do letters to the Commission requesting tax certificates provide such information.

168 See S. SurRey \& P. MCDANiEL, supra note 163, at 32-54 (explaining how most tax expenditure items are listed in the executive and congressional budget documents, but control of the programs is not integrated into the regular budget decision process); Simon, The Budget Process and the Tax Law, 40 TAX NotEs 627,628. 35 (1988) (pointing out that Congress does not coordinate tax writing and spending decisions because different committees have jurisdiction and because the executive branch has little control over Congress).

169 Fiscal year 1990 appears to be the first year in which FCC tax certificates 
expenditure budget prepared by the executive still does not include it. ${ }^{170}$ Even more than for other tax expenditure programs, the true cost of the tax certificate program is hidden from government decision makers and the public. Thus, it is hard to see how officials administering it have any incentive to keep the cost under reasonable control, even if they had the means of doing so. Nor is there any balancing of the social value of the program against all the other programs, both of the FCC and of all other agencies and departments, that compete for a slice of the federal budget. ${ }^{171}$

\section{B. Possible Responses to Tax Policy Concerns}

This analysis shows that the program's shortcomings are similar to other "tax expenditure" provisions of the Internal Revenue Code. ${ }^{172}$ Thus, some of the standard suggestions for improving tax expenditure programs in other areas may be appropriate here as well.

One such suggestion-that administrative responsibility be shared between the Internal Revenue Service and the administrative agency otherwise responsible for programs dealing with the same subject $^{173}$-has been used in this program since its inception. The FCC, which is the government agency with primary responsibility for protecting and advancing the public interest in broadcasting, determines eligibility for the tax benefit and processes applications for tax certificates. Then the IRS determines whether the seller meets the requirement of reinvesting in other property that is "similar or related in service or use" within the specified period, ${ }^{174}$ and ensures

have appeared on the congressional tax expenditure list. Compare STAFF OF THE JOINT Comm. ON TAXATION, supra note 24, at 15 (fiscal year 1990 estimates, listing a revenue loss from FCC tax certificates) with STAFF of THE JOINT CoMm. ON TAXATION, 100TH Cong., 2d Sess., Estimates of Fed. Tax Expenditures for Fiscal Years 1989-1993, (Joint Comm. Print 1988) (fiscal year 1989 estimates, not listing FCC tax certificates).

170 See OfFice of Mcmt. and Budget, Budget of the U.S. Gov't for Fiscal YEAR 1990, Special Analysis G, table G-1 (1989) (tax expenditure budget, not including FCC tax certificates).

171 See S. Surrey \& P. McDaniel, supra note 163, at 32-33 ("IE]very tax expenditure automatically has a higher budget priority than any direct spending program" because tax expenditures are not subject to the annual budget process. (emphasis in original)).

- 172 See id. at 31-98 (discussing problems in tax policy and.budget policy which are raised by tax expenditures).

173 See id. at 111-12 (describing requirement of certification from the Interior Department before IRS will allow a tax credit for historic building rehabilitation).

174 See 26 U.S.C. § 1033(a)(1) (1986). 
that the deferred tax ultimately is collected if and when the replacement property is disposed of by the seller. ${ }^{175}$

However, the problems of ineffectiveness, inefficiency, and lack of fiscal control that were described above have not been addressed. Tax expenditure analysis suggests that tax expenditures, when feasible, should be replaced with direct government spending programs. ${ }^{176}$ Instead of issuing tax certificates to sellers, the FCC could use other methods of assisting qualified minority entrepreneurs to enter the broadcasting industry. This assistance could take several forms: outright grants; contribution to a venture capital fund which would become a partner or investor in minority-controlled businesses; or provision of below-market-rate loans, or loan guarantees, for purchase of stations and for working capital.

Except for administrative expense, such programs would be highly efficient, because all of the benefits provided would go to minority broadcasters. Even administrative expenses might not be increased, because FCC staff already must process and examine tax certificate requests. Properly designed, a direct program would provide only the level of assistance for which a minority buyer showed need after exhausting all other available sources of capital. Such a program could prove more effective than the current system because minority buyers would bid for those stations which seemed most appropriate for their business plans, rather than those for which the sellers felt a special need to get a tax benefit. Finally, a direct program would be brought under the government's normal budgeting process, in which it would have to compete for funds with all other government programs, and there would be an actual decision each year about how much money the program should receive.

The tax certificate program is therefore a tax expenditure item that could be transformed into a direct spending program, with potential gains in efficiency, effectiveness, and fiscal accountability.

\section{Program Administration}

Assuming that the tax certificate program is lawful and constitutional, and that it should continue to be operated through the tax

175 For a complete discussion of IRS handling of FCC tax certificates, see generally Blake \& McKenna, supra note 42.

176 See S. Surrey \& P. MCDANiel, supra note 163, at 98; see also Simon, supra note 168, at 634-37 (arguing that the tax system would benefit from elimination of all tax expenditures; short of that, tax expenditures and direct outlays should be determined at the same time by one executive agency and one committee in each house of Congress). 
system rather than as a direct spending program, there remain questions about whether it is well designed to achieve its intended purpose effectively, efficiently, and without abuse. It could be improved in a number of ways. The following program weaknesses are readily apparent: (1) there is no assurance that the minority control of broadcasting that the Commission has purchased with lost tax revenue will be permanent, or even will continue for a substantial period of time; (2) there is no way to avoid giving far more tax benefit than is needed, in some cases, to achieve the desired result; (3) tax certificates are probably granted in circumstances in which minority ownership would have occurred without giving up tax revenue; and (4) there is no assurance that the program's goal-increase in viewpoint diversity and programming diversity-will be realized. Some of these weaknesses inhere in the existing program because the application procedure does not provide Commission staff with sufficient information to make better informed decisions.

\section{A. The Information Gap}

A request for a tax certificate is made to the Commission's Secretary by letter. It usually is made simultaneously with submission of an application for either "Consent to Assignment" of license, or "Consent to Transfer Control."177 Sometimes the request is made while the assignment/transfer application is under consideration, or even after consent to assignment or transfer is given. The request needs to establish only two facts: (1) that the Commission has consented to assignment or transfer, or that an approvable application has been made; and (2) that the assignee or transferee is a member of one of the specified minority groups, or is minority-controlled. No showing is required that diversity of ownership or diversity of programming viewpoints will increase as a result of the assignment or transfer. ${ }^{178}$ Upon a showing that minority control exists, the

177 See FCC Form 732, Mar. 1983.

178 Successful applications for tax certificates generally need only establish that the transferee will be minority-controlled. There is usually no discussion of diversification or programming issues. See, e.g., Letter from Linda J. Eckard (counsel for sellers of WPZZ(FM), Franklin, Ind.) to FCC Acting Secretary H. Walker Feaster, III (Mar. 11, 1988) (available in FCC license file of WPZZ(FM)) ("The proposed assignee corporation will be wholly-owned by Bishop L. E. Willis, who is a minority person. Therefore, the assignor requests that the FCC issue a tax certificate ... since a grant would further the FCC's minority ownership policies."); Petition for Issuance of Tax Certificate [for sale of KITV(TV), Honolulu, Hawaii] (filed Nov. 13, 1986) (available in FCC license file of KITV(TV)) ("All of the outstanding stock of Assignee corporation Tak Communications, Inc. is owned by Sharad Tak, a naturalized U.S. 
Commission apparently presumes that diversity of viewpoints and ownership will result.

The assignment application ${ }^{179}$ provides most of the information upon which the Commission staff bases its decision on the request. It provides complete information on ownership of the proposed assignee, its legal business structure, other existing media interests of the owners, and the terms on which the assignee is acquiring the assets. However, it provides no racial or ethnic information. ${ }^{180}$ The racial or ethnic identification of the assignee is generally alleged in the request letter or in a brief supporting document, but generally there is no material documenting or supporting the claim. ${ }^{181}$

The Commission also lacks other key items of information. It does not know how much gain the seller/assignor will realize on the transaction. It has no direct information on the financial capacity of the minority assignee, its ability to obtain credit, or its ability to purchase the station without government assistance. It does not know whether the minority buyer intends to retain and operate the station indefinitely, or contemplates reselling it. Nor does it know who will manage the station after the assignment. All of these information deficiencies are obstacles to optimal administration of the program.

\section{B. Permanent Minority Control}

When the Commission delays collection of thousands, or even millions, of dollars of tax revenue to facilitate the sale of a station to minority-group owners, it should have some assurance that minority

citizen and a Subcontinent Asian Indian. Pursuant to the Commission's rules and policies, Asians clearly qualify as minorities. . . . Of even more particular relevance ... the Commission issued a tax certificate to Liberty Broadcasting, Inc., which sold four television stations to . . a company 100 percent owned by Sharad Tak. . . For the foregoing reasons, the sale of stations KITV, KMAU and KHVO is necessary and appropriate to effectuate compliance with the Commission's policies regarding minority ownership of broadcast facilities, and thus the issuance of a tax certificate is warranted.").

179 See FCC Form 314, Mar. 1983.

180 See id.

181 See id. However, assignees sometimes submit statements affirming their minority status. See, e.g., Declaration of Gisela B. Huberman (controlling shareholder of proposed assignee of WLVW(FM), Salisbury, Md.) (May 29, 1986) (available in FCC license file of WLVW(FM)) ("I consider myself to be an Hispanic minority. I was born in Mexico and both of my parents were and are Mexican nationals. I retained my Mexican citizenship until becoming a naturalized United States citizen on January 9, 1968, Certificate No. 9037775. My native language is Spanish, and I have consistently identified myself as an Hispanic."). 
ownership will last. Currently, there is an opportunity for abusive but profitable transactions, in which, for example, a licensee sells to a minority buyer for a below-market price, but still earns a profit because of a tax deferral. The minority-controlled buyer then resells a year or two later to a non-minority person at something closer to market price, turning a quick profit. The result is great cost to the government, economic benefit to both the recipient and a minority entrepreneur, but no increase in permanent minority ownership. The Commission apparently recognized this abuse opportunity, and announced that minority buyers under tax certificates may not re-sell for one year unless it is to another minority buyer. ${ }^{182}$ However, this does not provide sufficient protection for the integrity of the minority-ownership policy. A good example of the problem is the 1987 grant of a tax certificate to Gaylord Broadcasting Company on the sale of television station WTVT in Tampa, Florida. ${ }^{183}$ A shareholder agreement, which was provided to the Commission, gave the nonminority-group shareholder an irrevocable option to buy out the minority-group shareholder (who was otherwise in legal control) ${ }^{184}$ on very favorable terms any time during the third, fourth, and fifth years following commencement of the business. ${ }^{185}$ This arrange-

182 The one-year holding rule was re-imposed on persons who acquired stations under any of the racial preference programs, in order to avoid defeating the purpose of those programs. This action came after the Commission had abolished its previous "anti-trafficking" ' rule, which generally barred assignment of a license until it has been held for three years. The one-year rule currently also applies to a person who has received a license in a comparative hearing. See Amendment of Section 73.3597 of the Commission's Rules, 99 F.C.C.2d 971, $971-72$ (1985); 47 C.F.R. $\S 73.3597$ (1987).

183 See Tax Certificate, supra note 59.

184 Clarence McKee, a black, owns 210 shares of "class A" stock, which carries four votes each. Gillet Group, a non-minority entity, owns 790 shares of "class B" stock, which carries one vote each. Thus, McKee controls $51.53 \%$ of the votes and is legally in control of the licensee, WTVT Holdings, Inc. See Request for Issuance of Tax Certificate, filed by Gaylord Broadcasting Co. (Mar. 20, 1987) (available in FCC license file of WTVT(TV)).

185 See WTVT Shareholder Agreement, supra note 59, at 7, 10. Under the agreement, neither shareholder may dispose of its interest without the consent of the other. Id. at 2. Also, each has a right of first refusal in the event the other wants to sell any shares. Id. at 2-3.

If Gillett exercises the option, McKee will receive one million dollars or a fraction of the company's then net worth (based on his proportion of stock ownership), whichever is more. Id. at 10. The station was purchased for $\$ 365$ million in 1987. See Asset Purchase Agreement between WTVT Holdings, Inc. and Gaylord Broadcasting Co., at 5 (Mar. 5, 1987) (available in FCC license file of WTVT(TV)). WTVT Holdings, Inc. was capitalized at only $\$ 1,000$, and the purchase was entirely financed with borrowed money. See Articles of Incorporation of WTVT Holdings, Inc. (Mar. 4, 1987); WTVT Shareholder Agreement, supra, note 59, at 1 
ment not only fails to provide a reasonable assurance of permanent minority control, but it creates a strong suspicion that minority control is intended to be temporary. The grant of this tax certificate has been strongly criticized. ${ }^{186}$ Even though there are unofficial indications that the Commission would not approve such an arrangement today, ${ }^{187}$ the Commission has not published any statement on the matter, ${ }^{188}$ thus creating confusion about its actual policy position.

The Commission should establish a policy that it will not approve a transfer of control or assignment of a tax certificate property to a non-minority-controlled entity for a substantial period of time-say five years-unless the licensee proves that it is incapable of continuing operation, and that it has made a good faith effort to find a new minority-controlled buyer. In addition, the Commission should refuse to issue a tax certificate if, as in the WTVT case, the transaction documents create any reason to doubt that the license will remain under minority control for an indefinite period. The administration of the program should remain true to its goal, which is to encourage increased viewpoint-diversity through permanent minority control of broadcast facilities.

\section{Limiting the Amount of Tax Deferred}

Because a tax certificate allows deferral of capital gains tax by the seller, the larger the amount of gain to be realized in a sale, the more incentive there is to find a minority buyer. It is therefore likely that in many cases the benefit the seller receives from the tax certificate exceeds the amount of subsidy needed to bring about minority

("[T]he Class B Shareholder has agreed to arrange financing for the Purchase upon the condition that the Class A Shareholder enter into this Agreement ...").

186 See Vise, Minority Broadcasters' Tax Break Hit, Wash. Post, Jul. 12, 1987, at H1, $\mathrm{H} 6$, col. 1. "Facades like that can damage the purpose of policies that give minorities the chance to participate in broadcasting. That is nothing but a sham. It appears to be a front operation." Id. (quoting Rep. Mickey Leland (D-Tex.)); "[D]eals like WTVT drive out bona fide purchasers. We do feel strongly this process should not be abused." Id. (quoting communications lawyer Charlie Firestone).

187 See Richter, Entrepreneur Builds Broadcast Empire on Debt, L. A. Times, Dec. 27, $1987, \S 4$, at 1, 4, col. 2 ("While FC.C officials insist that the Tampa deal was proper, the notoriety of the transaction seems to be changing regulators' attitudes. Already, FCC staff members have discouraged several minority tax certificate proposals that were floated by them for preliminary review, according to an investment banker with firsthand knowledge of the proposals. 'The legacy of that deal is that it is going to be much tougher for others,' the banker said.").

188 The Gaylord Broadcasting certificate, like all others since 1980, was approved by the Commission sraff without any published opinion or other explanation of the decision. 
control of the station. In the WTVT case, it appears that Gaylord will be able to defer more than one hundred million dollars in tax liability. ${ }^{189}$ It is reported that the New York Times Company received a tax benefit of fifty-five million dollars under a tax certificate issued for the $\$ 420$ million sale of its southern New Jersey cable television operations. ${ }^{190}$ A radio group owner who has purchased a number of stations under the program said that he generally can buy for about twenty percent less than ordinary market value, ${ }^{191}$ indicating that his vendors realized tax savings of more than twenty percent of the sale price. Forsaking such large amounts of tax revenue to achieve minority ownership of a single television station or other facility is wasteful and excessive.

A limit should be placed on the amount of capital gains tax that can be deferred under the program. Section $1071^{192}$ should be amended to provide that when the FCC certifies a transaction, the gain realized may receive involuntary conversion treatment up to a limit of thirty percent of the sale price of the property. At the current maximum corporate tax rate of thirty-four percent, ${ }^{193}$ and the top individual rate of twenty-eight percent, ${ }^{194}$ such an amendment would permit deferral of tax liability up to approximately ten percent of the sale price. This should compensate for any reasonable extra transaction costs that would be involved in arranging a sale to a minority buyer, and still provide an incentive for the desired behavior without overcompensating. Using a percentage of sale price limitation is preferable to a flat dollar limitation because the percentage approach will provide effective incentive for minority ownership of large as well as small stations. This approach will not provide an exact match between the amount of government assistance provided

189 In a financing memo circulated by the investment banking firm Drexel, Burnham, Lambert, Inc., Gillett says that "[t]he $\$ 365$ million purchase price for WTVT is approximately $\$ 135$ million below [Gillett's] estimate of its market value." Vise, supra note 186, at H6, col. 1. "Gaylord had owned the Tampa station for 30 years, purchasing it in 1956 for about $\$ 4$ million. With its investment in the station quite low, Gaylord's potential tax liability from the sale could have exceeded $\$ 100$ million, Wall Street sources said. Gaylord officials declined to comment about the minority tax certificate . . ." Id. See also Vaughan, Television Tycoon: George Gillett, Jr., N.Y. Times, Aug. 28, 1988, $\S 3$, at 9, col. 1 (estimating that the tax certificate allowed deferral of $\$ 110$ million in tax).

190 See Phila. Inquirer, Jan. 10, 1989, at 1, col. 1 (announcing deal).

191 See Gnoffo, He Has an Ear for Radio Stations, Chicago Tribune, Sept. 17, 1989, at 13C (explaining how Philadelphia lawyer Ragan Henry used the program to build the largest radio station chain in the country).

192 See supra note 40 and accompanying text.

193 See 26 U.S.C. § 11 (Supp. V 1987).

194 See 26 U.S.C. $\$ 1$ (Supp. V 1987). 
and the amount needed to achieve the desired result. Alternatively, the Commission could require a minority buyer to justify a particular amount of tax deferral requested by her vendor and show that it is necessary to the transaction. However, such a rule would require very subjective evaluations of the situation of each prospective seller and each prospective minority buyer, and could be quite difficult for the Commission to perform fairly and accurately. Either plan would be an improvement over the current open-ended program, which has no limits on how much the government "spends."

\section{Group Owners and Station Management}

The tax certificate program is justified in the name of increasing viewpoint-diversity through minority ownership of broadcasting. This justification raises two questions: (1) should eligibility for a tax certificate depend on how nany media interests the minority-group buyer already owns, and (2) should it be relevant whether minoritygroup persons will manage the station after the assignment or transfer? The current program treats both of these factors as irrelevant. This rule is unjustifiable in light of the overall policy goal of increasing diversity.

Suppose a profitable radio station that has been independently owned by a local owner-manager is sold under the program to a minority-controlled concern, headquartered in another state, that owns other broadcast properties. The new owner retains the staff, appoints a manager who is not a minority person, and instructs the manager to make no changes in the operation and to continue the existing programming format. There is now one less owner of radio stations than before the transaction. The station involved is now under absentee rather than local ownership, and the service provided by the station is essentially the same as before. It is difficult to justify a presumption that cliversity of ownership or viewpoints has been increased. In fact, diversity of ownership has been reduced, and programming viewpoint has not been changed, while the new hired manager of the station might be less sensitive to local conditions and needs than the former owner. An example of such an owner is Philadelphia lawyer Ragan Henry, who reportedly purchased twenty-eight radio stations across the country in a span of twenty months using tax certificates. He denies having a "Black" 
programming viewpoint; instead he programs whatever he thinks will make the most money in each market. ${ }^{195}$

In the context of comparative hearings, the Commission has long favored applicants who have less existing media interests over those with more, and applicants who propose to have ownership "integrated" in management over those who do not. The same criteria could also be used to decide whether to grant a tax benefit for a particular transaction, or (if the statute were changed) how much benefit to allow. For example, if the buyer is already well established in the broadcasting industry, and owns a number of stations, it is reasonable to assume that the buyer (even if minority) does not need government assistance to acquire additional stations. Sharad Tak is a case in point. In a span of five years, Mr. Tak, who qualifies as a minority person because he is a naturalized native of India (AsianAmerican), purchased all or controlling shares of six television stations with the aid of tax certificates. One has since been re-sold. ${ }^{196}$ It is recognized that $\mathrm{Mr}$. Tak is now a rich and powerful man. ${ }^{197}$ While there is nothing wrong with wealth, there is no reason why an

195 See Gnoffo, supra note 191.

196 The Commission approved assignment of KTBY(TV), Anchorage, Alaska, from Totem Broadcasting Corporation to KTBY, Inc. (controlled by Mr. Tak) on July 11,1984 , and a tax certificate was issued. Five months later, on December 21, 1984, Mr. Tak sought permission to transfer control of KTBY, Inc. to Ronald Bradley, the General Manager of the station. The Commission gave consent on December 31, 1984. See FCC Form 732 Consent to Assignment (Jul. 11, 1984) (available in FCC license file of KTBY(TV)); FCC Form 314 (May 23, 1984) (available in FCC license file of KTBY(TV)); Minority Ownership Lists, supra note 18; Letter from Kevin F. Reed, counsel for KTBY, Inc. to FCC Secretary William J. Tricarico (Dec. 20, 1984) (explaining proposed transfer of control to Mr. Bradley) (filed with Commission Dec. 21, 1984) (available in FCC license file of KTBY(TV)); BroADCASTING/CABLECASTING YEARBOOK 1988, at C-1 14 (noting FCC approval of transfer to Bradley).

Mr. Tak currently owns WGRZ-TV, Buffalo, New York (agreement to purchase for $\$ 100$ million, subject to FCC approval, announced May 2, 1988). See Business FIRST - Buffalo, May 9, 1988, § 1, at 8 . He owns KITV(TV), Honolulu, Hawaii (plus two satellite stations) (approved Jan. 27, 1987). See BroadCAsting/CABleCAsting YEARBOOK 1988, at C-21. Tak also owns four Wisconsin TV stations: WKOW-TV, Madison, WXOW-TV, LaCrosse, WQOW-TV, Eau Claire, and WAOW-TV, Wausau, (all approved Jan. 7, 1985, except WQOW-TV, approved Jan. 24, 1985). See id. at C140, C-141. Tax certificates were issued for each transaction. See Minority Ownership Lists, supra note 18.

197 See Leslie, The Fourth Annual Regardie's 100: The Richest People in Washington, Regardies The Business of Wash., Sept. 1988, $§ 1$, at 85 (listing Mr. Tak as among the 100 richest Washingtonians and describing his businesses). At the time he purchased WGRZ-TV for $\$ 100$ million, Mr. Tak was also controlling stockholder of ST Systems Corporation, "one of the country's leading providers of software to the National Aeronautics and Space Administration, the Federal Aviation Administration and the Department of Defense." See N.Y. Times, May 4, 1988, at D20, col. 5. 
already well-established entrepreneur with considerable financial resources and presumably ready access to the credit market should continue to benefit from a program which was created because of concern about the difficulties that minority persons have in breaking into the broadcasting industry.

In the past, the question of who will manage a station after assignment has been considered immaterial in determining whether a seller is eligible for a tax certificate. This policy is misguided. A tax certificate should not be granted unless there are assurances that minority persons will actively be involved in the day-to-day management of the station. Mr. Tak apparently is not involved in the daily operation of any of his stations, since he lives in Maryland, and the stations are all located in other states. ${ }^{198}$ The Commission already requires minority-group owners to be "integrated" into daily management for them to receive enhancement credit in a comparative licensing proceeding. ${ }^{199}$ The requirement is quite reasonable, because it helps to justify the Commission's presumption of public benefit through increased viewpoint diversity, a presumption which underlies all of the Commission's minority preference programs. The same condition should apply before a minority-ownership tax certificate is issued. ${ }^{200}$

\section{Conclusion}

Racial minorities historically have been poorly represented, both in broadcast programming and in ownership of broadcast stations. The Commission's tax certificate program, which was developed out of policies favoring equal employment opportunity, diversity of viewpoints in broadcast programming, and the desirabil-

198 See Leslie, supra note 196 (listing Mr. Tak as a resident of Potomac, Maryland).

199 See supra notes 31-37 and accompanying text.

200 I do not suggest that buyers in tax certificate cases be required to show how they will increase viewpoint diversity in the market. That would require making promises concerning future programming. The Commission wisely has abstained from exercising control over the programming decisions of licensees. See Formulation of Policy Relating to the Broadcast Renewal Applicant, 66 F.C.C.2d 419 (1977) (declining to adopt percentage guidelines for local programming, news, and public affairs on television stations), aff'd sub nom. National Black Media Coalition v. FCC, 589 F.2d 578 (D.C. Cir. 1978); Changes in the Entertainment Formats of Broadcast Stations, 60 F.C.C.2d 858 (1976) (abandoning efforts to preserve diversity in radio formats by regulation and concluding that the public interest is best served by allowing licensees the freedom to change formats in response to market forces), rev'd sub nom. WNCN Listeners Guild v. FCC, 610 F.2d 838 (D.C. Cir. 1979), rev'd, 450 U.S. 593 (1981) (upholding Commission). 
ity of minority ownership of stations, has increased the number of minority-owned stations over the past 10 years, although ownership remains substantially below the percentage of minority groups in the population.

The Commission launched this racial classification program without any specific statutory authority, and without ever finding that it was necessary to remedy past racial discrimination in the industry. Only when an appellate court and the Commission itself questioned the legality of the program did Congress intervene and give it's afterthe-fact approval. As currently established and justified, the program probably could not pass the equal protection standards for affirmative action programs as reflected in the Supreme Court's decision in the City of Richmond case. The companion distress sale policy has been held unconstitutional as applied by the court of appeals. The Supreme Court has granted review in this case, and in another case that raises the consitutionality of the companion comparative merit preference policy. However, Congress probably has the power to overcome any constitutional objections by making appropriate findings and re-authorizing the program.

The current program is implemented as a "tax expenditure," which inevitably introduces inefficiencies, and impairs the ability of the Commission to control the magnitude and operation of the program. Conversion to a direct spending program would offer significant advantages.

Even if the program is lawful and should continue to be operated through the income tax system, it suffers from administrative weaknesses which make it vulnerable to abuses which compromise the viewpoint-diversity rationale. These problems could be lessened through more careful program design, which would also reduce the risk that the program would be invalidated as not narrowly tailored to achieve compelling governmental interests.

Despite the problems with the Commission's program, its objective is worthwhile. American society needs diverse broadcast programming, which includes full and fair presentation of minority viewpoints. Minority ownership probably contributes to this objective, ${ }^{201}$ though it is certainly not the only means by which the objective might be pursued.

201 See Congressional Research Serv., Library of Cong., Minority Broadcast Station OWnership and Programming: Is There a Nexus (June 29, 1988), at cover page (indicating minority- and female-owned stations provide more minority- and female-oriented programming than non-minority or -female owned stations, respectively). 
Finally, the symbolic importance of Commission policies such as equal employment opporturity and viewpoint-diversity can hardly be overlooked in our diverse society. To quote former FCC Commissioner Tyrone Brown:

[T] he FCC's commitment to minority participation always has had a greater significance than is indicated by the current level of minority ownership. That significance is illustrated by the comments of a very successful minority programmer who has never been a direct beneficiary of the agency's minority initiatives but is convinced nonetheless that 'the very existence of the FCC's commitment has opened doors in the private sector that otherwise would have been closed to me. 202

The Commission should retain and strengthen its twenty year commitment to minority participation in the broadcasting industry. Criticism of the current tax certificate program is no reason to retreat from the policy. Instead, it points the way toward what can be done to make the policy more effective and efficient.

202 Brown, The FCC's New Threat to Minority Preferences, Wash. Post, Sept. 26, 1986, at A-27, col. 4. 